\title{
Planning Law in England and Wales and in the United States
}

\author{
J, F. Garner, LL.D. and D. L. Callies, A.B, J.D., LL.M.
}

\section{INTRODUCTION}

In these two articles, an attempt has been made to summarize planning law in two very different countries; different, that is to say, geographically and as to their governmental organization, but similar in that the two countries have a common legal heritage and cultural tradition.

[Part I and the Comparative Conclusion have been written by Professor Garner; Part II by Mr. Callies.]

\section{I: Planning Law in England and Wales}

\section{The Governmental Structure}

England and Wales, ${ }^{1}$ being a unified country with a single legal system and administrative organization, possesses initial advantages in planning law in comparison with the United States. Legislation may be passed for the whole country, without the complications of either a federal structure or of a Supreme Court endowed with power to declare legislation unconstitutional. Legislation within a state in the U.S. often takes the form of an Enabling Act, which empowers a municipality to take certain action; England knew the device of the "Adoptive Act" in the 19th century, but has long since abandoned this variety of "home rule", and any modern administrative statute will be automatically in force throughout the country once it has been brought into operation. ${ }^{2}$ More important perhaps in a planning context, the presence of a unified administration makes possible the establishment of a single central Government Department charged with the duty of supervising the planning machinery at local level; for land use planning is a local governmental function, although it must clearly be integrated with regional and national policies.

The legislation, of general application throughout England and Wales, ${ }^{3}$ was originally enacted, substantially in its present form, in the Town and Country Planning Act, 1947, passed by a Socialist Government but based

${ }^{1}$ So far as planning law is concerned England and Wales is but a single jurisdiction, but in matters of local government administration. England and Wales respectively are separately provided for in the Local Government Bill 1972. In all senses Scotland is a separate jurisdiction with its own legislation, so is Northern Ireland.

a Most planning statutes are brought into effect by commencement orders made by the Minister under powers given him in the statue; Part I of the Town and Country Planning Act 1968, for example, was brought into effect on different days for different areas of the country.

The first planning statute was the Housing and Town Planning, etc. Act, 1909, but the first major enactment that provided for "interim development control" (without any enforcement power) throughout the country, was the Town and Country Planning Act, 1932. 
for the most part on reports prepared under the war-time coalition government. The 1947 Act was amended in details and replaced by the consolidating Act of the same name of 1962 . This in time was amended, principally by an important Act of 1968 which radically changed the format of development plans, tightened up the procedure for enforcement of development control, and introduced a new system of control over ancient buildings. The law was then again consolidated by the Town and Country Planning Act 1971, which is now the principal statute in force, but this is already being amended in points of detail by the Town and Country Planning (Amendment) Act 1972, and by the Local Government Bill 1972.

In England therefore the Secretary of State for the Environment (and his subordinate, the Minister for Land and Planning) is responsible for national town and country planning policy and for a general supervision over the activities of local planning authorities throughout the country. This supervision is exercised indirectly rather than directly, for local planning authorities are not outposts of the central government, but are independent legal entities, responsible to a local electorate and dependent for their financial resources at least in part" on taxes (known as "rates") locally assessed and levied. The means by which central supervision is exercised by the Secretary of State (hereafter called "the Minister" may be summarized as follows:

(1) By initiating and promulgating legislation when reforms in the legal structure are considered necessary, ${ }^{5}$ and by supplementing statutory provisions by regulations or directions within the powers expressly conferred on the Minister by Parliament;

(2) By approving (with or without modifications) or, indeed, by withholding approval of, development plans and tree preservation and other orders, and also orders for the compulsory acquisition of privately owned land made by local planning authorities;

(3) By hearing and determining appeals against refusals of planning permission; ${ }^{6}$

(4) By the making or withholding of grants to local planning authorities for particular specified purposes; this control by the "carrot" rather than the "stick" is not nearly so common in English practice as it is in the United States, but 50 per cent. grants may be available towards projects for the re-development of central areas or the reclamation of waste land;

(5) By general advice, in circulare or memoranda, for which there is no legal backing, but which will normally be accepted and followed by the local authority. In practice this has proved over the years to be a most effective means of supervision.

"Below" the Minister at present are to be found some 150 planning authorities; the county councils and county borough councils which, together with the Greater London Council,? cover the whole area of England and Wales. This local government structure is at present under review, and by 1974 there will be only 44 county councils which will be the local planning

- The financing of planning activities is considered to be outside the scope of this paper.

${ }^{3}$ The Town and Country Planning Act 1968, for example, was very largely the result of a report of a Planning Advisory Group (affectionately known as PAG) of experts within the Ministry.

- The Minister also has power to "call in" a particular application for development and decide it himself, as if he were the planning authority; this is a power used only in exceptional circumstances.

7 The Greater London Council is the local planning authority for Greater London (an area with a population of about $9 \mathrm{~m}$.) but there are also 32 London boroughs and the City of London, who have quite considerable planning functions, including in particular the control of development. 
authorities for their areas, and these will between them cover the whole country outside London (including the areas of the existing county boroughs). ${ }^{8}$ Outside the county boroughs (which are "all purpose" local authorities) there is at present a second "tier" of local authority, the non-county boroughs, the urban district councils and the rural district councils; throughout the country there are some 1,400 of these authorities. These second-tier authorities are not local planning authorities, but they receive all applications for planning permission, and they have certain powers of acquisition of land for planning purposes. ${ }^{10}$

\section{Strategic Plans}

It was the duty of every local planning authority to prepare a development plan for its area under the 1947-62 Acts. This was designed to show the optimum land use for land in the authority's area. Under the 1968 and 1971 Acts, however, ${ }^{11}$ this duty remains, but future development plans are to be prepared at two distinct stages; the "structure plan" and the "local" plan. The structure plan (which consists principally of a written statement supplemented by illustrative diagrams) is designed "for dealing with and setting out strategic issues, and the local authority's policy and general proposals on them for a period broadly of 20 years ahead". ${ }^{2}$ The plan will, of course, be primarily concerned with land use, but it has to take into account also the educational and recreational needs of the area, industry, communications and traffic management, public utilities and social requirements, as well as the economic resources of the area, and all these considerations must be integrated with relevant national and regional policies.

Wide consultations between the local planning authority and other public bodies must take place while the structure plan is being prepared, and proposals must be generally made known in the locality so that interested persons may make observations which must be taken into account by the authority. ${ }^{13}$ After this preliminary stage a draft structure plan must be prepared and publicly advertised; it is then submitted to the Minister for his approval. Members of the public, local amenity societies and others concerned are entitled to make objections to the Minister. When such objections are made the Minister must direct some person or persons appointed by him to hold a public "examination" of such matters as he considers ought to be examined; an objector is not entitled as of right to be heard at this examination, but the Minister must take any such objections into account (and also, presumably, the report of the public examination) ${ }^{15}$ before deciding whether or not to approve the structure plan, with or without modifications.

${ }^{8}$ Local Government Bill 1972. There will in addition at a lower level be some 300 "district councils", which will exercise most of the powers of development control and also will be responsible for preparing "local plans" (see para. 3 below).

Development control functions may be delegated to them, under the county planning authority's general guidance.

10 Town and Country Planning Act 1972, s.112, and see below, para. $6(d)$.

11 See now 1971 Act, Part II.

12 Ministry Circular 44/71, memo. para. 13.

13 1971 Act, s.8. There may be more than one structure plan for the area of a single planning authority, and two or more authorities may combine to prepare a single plan.

16 T. \& C.P. (Amendment) Act 1972, s.3; strangely enough there is no express requirement that the Minister shall take the report on the examination into account. 
The structure plan, however, forms part only of the development plan; the structure plan must define "action areas" that it is anticipated will be subjected to "comprehensive development"15 within a period of 10 years from the making of the plan; also areas should bo identified which will be the subject of "local plans". It is not made a statutory requirement that any action areas or areas for local plans should be identified in the structure plan, but in practice it is clearly the intention that they will be.

\section{Tactical Plans}

Where an area has been defined in a structure plan as an action area or an area for a local plan, a local plan must be prepared by the local planning authority or, after local government re-organization under the Local Government Bill 1972, by the (newly formed) local district council. ${ }^{16} \mathrm{~A}$ local plan may be prepared contemporaneously with the structure plan, but it must not conflict with any of the provisions of the structure plan, and it cannot come into operation until the structure plan has been approved by the Minister.

A local plan is a tactical plan, an indication of the planning authority's proposals for implementation of the structure plan policy; local plans are "designed to enable the local planning authority to formulate, in appropriate detail, their proposals for implementing or filling out the policy and general proposals of the structure plan, within the time scale of that plan." they will deal in more detail with questions of land use, after the preliminary stages of making the plan, the statutes require the authority to hold a public local inquiry, at which any objector (landowner or other person interested) will be entitled to appear and develop the subject matter of his objection before an inspector, appointed by the authority. The authority must consider any such objections, and may then adopt the plan; they will not (except in a case where the Minister may have expressly so provided) need to obtain the Minister's approval to a local plan.

A local plan may be of three kinds: ${ }^{18}$

(a) A "district plan", based on a comprehensive consideration of matters affecting the development and other use of land in the area;

(b) An "action area plan", dealing with the comprehensive development of the action area; or

(c) A "subject plan", based on a consideration of a particular description or descriptions of development or other use of land in the area to which it relates.

In practice objections from individual landowners will be much more likely at the local plan stage; objections to structure plans could relate only to points of principle, such as, for example, that a proposed by-pass to a town should pass to the east rather than the west of a town, or that there should not be a by-pass at all. Objections to local plans are, however, much more likely to deal with particular plots, such for example as the objector who does not want the by-pass at the bottom of his garden.

However, development plans are merely indicative of the planning authority's views about the development that should or should not take

${ }^{15}$ An expression which is not defined in the statutes.

${ }^{10} \mathrm{~A}$ scheme must be made for the preparation of local plans by the various district councils within a county planning authority's area.

17 Circular 44/71, memo. para. 19.

${ }^{18}$ Town and Country Planning (Structure and Local Plans) Regulations 1971 (8.1. 1971, no. 1109, reg. 15). 
place; planning permission must still be obtained before any development takes place. Moreover, there is no assurance that such permission will be granted even for development that is in accordance with the development plan; even local plans are often drawn in general terms in relation to the land use of particular plots, plans are subject to alteration (1971 Act, s.15), and the Secretary of State may approve a departure from the plan in a particular case; moreover, a developer may still have to overcome objections from the planning authority based on such matters as highway access, plot density, and architectural design.

The legal validity of a development plan (either the structure or a local plan) may be called into question on the ground that it was ultra vires, or that the procedure has not been complied with in some material respect, by means of an application to the High Court by a person aggrieved, and the plan may then be quashed in whole or in part (1971 Act, s.244). This right of appeal has existed since the 1947 Act was passed, but it has never been used in practice and indeed it would be extremely difficult to show that the provisions of a development plan were ultra vires or that there has been a material error of procedure.

\section{Development Control}

In many senses development control is the centre-pin of the whole legal planning structure; it is certainly the facet of planning law that impinges most sharply on the individual landowner. Development is very widely defined, ${ }^{19}$ and with certain exceptions, ${ }^{20}$ it is made illegal to carry out any development without first obtaining planning permission.

Applications for permission must be made to the local district council for onward transmission to the local planning authority for a decision; ${ }^{21}$ they have a wide discretion whether or not to grant permission, and they may impose conditions (of a planning nature) ${ }^{22}$ in any case when granting permission. In exercising this discretion the authority must have regard to the provisions of the development plan, "so far as material to the application and to any other material considerations. ${ }^{.23}$ If planning permission is refused, or permission is granted subject to conditions, the authority must state reasons for their decision, and the applicant will have a right of appeal to the Minister. On such an appeal the Minister will convene an inquiry to be conducted by an inspector (a civil servant from the Department of the Environment) appointed by him and a judicial type of procedure will be

19 "Development" means "the carrying out of building, engineering, mining or other operations in, on, over or under land or the making of any material change in the use of any buildings or other land", 1971 Act, s.22. This definition is subject to specified exceptions, such as changes of use for the purposes of agriculture or forestry, and changes of use within classes specified in an Order made by the Minister (see the T. \& C.P. Use Classes Order, 1963); the definition has also been the subject of a considerable quantity of case law.

201971 Act, 8.23. The principal exceptions are contained in the T. \& C.P. General Development Order 1963 (as amended) made by the Minister under $\$ .24$ of the 1971 Act and its predecessors.

21 In some cases power to determine the application may be delegated to the district council by the planning authority; under the Local Government Bill 1972, the law will provide for a number of applications to be determined by the (new) district council.

${ }^{22} \mathrm{~A}$ condition, for example, fixing the rents to be charged for caravans brought onto a site was held to be ultra vires, in Mixnam's Properties Ltd. v. Chertsey U.D.C. [1965] A.C. 735 (H.L.).

${ }^{23} 1971$ Act, 8.29. 
followed, at which the appellant will be entitled to call witnesses and to cross-examine witnesses called by the planning authority. In some 60 per cent. of all such appeals (i.e. in all less important cases) ${ }^{25}$ the inspector will himself determine the appeal on behalf of the Minister; in the more important cases, the inspector will write a report on the inquiry held by him, and the decision will then be made by the Minister after considering the report (but not necessarily accepting any recommendations therein contained). ${ }^{26}$

If there is a "breach of planning control" (i.e., if development is carried out without first obtaining planning permission, or if there is a failure to comply with a condition or a time limitation in a planning permission) the planning authority may serve an enforcement notice on the owner and occupier of the land in question, requiring the breach of control to be remedied. ${ }^{27}$ Normally ${ }^{23}$ this notice must be served within a period of four years from the occurrence of the breach, and there is a right of appeal to the Minister against the notice given to any person on whom it has been served. On such an appeal, after a local inquiry, the Minister may confirm or quash the notice, or he may correct any informality, defect or error in the notice that he considers is not material, or he may vary the terms of the notice in favour of the appellant..$^{20}$ A further right of appeal on a point of law or procedure lies from a decision of the Minister to the High Court, at the instance of either an aggrieved person or of the local planning authority. ${ }^{80}$

Failure to comply with the provisions of an enforcement notice (subject to the rights of appeal), renders the owners and occupiers of the land affected liable to a prosecution for an offence; in addition the local planning authority will in an appropriate case have power to enter on the land and (for example) pull down any building erected without planning permission and recover their expenses thereby reasonably incurred from such owner(s).

The power to serve an enforcement notice is supplemented by powers to serve two different kinds of subsidiary notices:

(a) First, in a case where an enforcement notice has been served in respect of a breach of planning control consisting of the carrying out of operations (as distinct from a change of use) the authority may serve a stop notice requiring, under pain of criminal proceedings, the immediate cessation of the offending operations. notice is to prevent (for example) the continuing construction of a building while the legal or planning validity of an enforcement notice is being argued out by way of appeal to the Minister and possibly to the courts. If it subsequently turns out that an enforcement notice was invalid or that planning permission should be granted in respect of the operations in question, compensation will be payable by the planning authority in respect of any loss suffered as a consequence of the service of a stop notice.

\footnotetext{
24 Very closely regulated by the T. \& C.P. (Inquiries Procedure) Rules 1969.

23 These are specified by regulations (the T. \& C.P. Determination of Appeals by appointed persons) (Prescribed Classes) Regulations 1970). The figure of 60 per cent. is an estimate of the proportion of the cases decided by inspectors, given by the Ministry in 1971.

${ }^{20}$ Nelsovil v. Ministry of Housing and Local Government [1962] 1 All E.R. 423.

${ }^{27} 1971$ Act, 6.87 .

${ }^{23}$ Except in cases of change of use, other than a change of use from that of any building to that of a single dwelling-house: s.87(3).

291971 Act, s.88.

${ }^{3}$ Ibid., 8.246.

31 Within a period (to be stated in the notice) of from three to 14 days : 1971 Act, s.90, and see 8.171 .
} 
(b) Second, where a developer has obtained planning permission but has not completed the development to which the permission relates within a reasonable time, the authority may serve a completion notice requiring the completion of the development within a time stated, not less than twelve months later; in default of compliance with such a notice the planning permission becomes void. ${ }^{32}$

These notices, especially enforcement notices, are highly technical documents, the procedure has to be followed exactly and the courts will be ready to invalidate the notice for comparatively minor errors. ${ }^{33}$ However, the service of an enforcement notice is comparatively rare ${ }^{34}$ and stop notices, perhaps because of the liability to pay compensation, are even rarer. Development control without powers of enforcement is of course meaningless, but the threat created by the existence of the powers is often sufficient; a purchaser of land, for example, invariably inquires into the planning history of the land, and will not normally buy land that may become the subject of an enforcement notice.

\section{Ancillary Controls}

The control of development and its enforcement, fundamental as it is to the restrictive aspect of planning law and administration, is not, however, sufficient; certain kinds of interference with the environment, not in themselves amounting to development, are thought to need to be brought under special control. These include restrictions on alterations to buildings of special architectural or historic interest (here described as "historic buildings"), the display of advertisements, the felling of trees and woodlands, the starting of caravan sites, waste land and the cessation of non-conforming uses.

(a) Historic Buildings. The Minister or local planning authority may include in a list any building which seems to be of a special architctural or historic character; once this has been compiled or approved by the Minister ${ }^{35}$ it becomes an offence to demolish, extend or alter the building that will affect its character as a building of special architectural or historic interest. If the owner wants to demolish or alter such a building, he may apply to the local planning authority for "listed building consent". and if this is refused, he has a right to appeal to the Minister; if the building is altered, etc., without a listed building consent first being obtained, proceedings for a criminal offence may be taken, or a "listed building enforcement notice" may be served. Further, if the owner of a listed building fails to keep it in proper repair the local planning authority may acquire it compulsorily and in certain circumstances the owner will receive only a low rate of compensation in respect of the acquisition. ${ }^{86}$

Even these far-reaching powers have not been thought sufficient to protect the nation's stock of old buildings. Any individual building that has been missed from the approved list can be "held" for a period of six months by the service of a building preservation notice, and any

so Ibid., 6.44.

* See such cases as Burgess \& Jervis v. Sevenoaks R.D.C. [1952] 1 All E.R. 592, and Courtney-Southam v. Crawley U.D.C. [1967] 2 All E.R. 246.

$\boldsymbol{s}$ In the year 1967 , for example, there were 422,553 planning applications, but only 2,274 appeals against enforcement notices, of which the Minister allowed 31 per cent. (quashing or modifying the notice in these cases).

ss 1971 Act, s.54. Notice has to be given to the owner of the "listing" but he has no right to object thereto.

so 1971 Act, 8.117. 
buildings within a conservation area $a^{37}$ may also be subjected to control as if they had been listed, by "directions" made by the local planning authority.38

These provisions do not, however, really cater for the case where the owners of a historic building do not have sufficient financial resources to keep it in proper repair. Local authorities may make grants in such cases, ${ }^{39}$ and so may charitable bodies; also in some cases the Treasury may accept as a gift to the nation an ancient building in lieu of payment of death duties, and in such cases the property is often handed over to the National Trust for them to maintain the building and make it available for visits by the public. Many old buildings, however, that do not have any very special historic associations may be thought worth preserving, but are not really commercially viable; it is not clear how these, often in our industrial towns, will be able to survive the pressures of development for new ring roads or for modern office or factory blocks.

(b) Advertisements. The control of advertisements is effected by a separate code of law contained in regulations made under s.63 of the 1971 Act and its predecessors. ${ }^{40}$ It is an offence, subject to certain very closely defined exceptions, mostly in relation to commercial premises, to display any advertisement without the prior consent of the local planning authority. Consent may be applied for to the authority and if refused (which may be only on the grounds of amenity or safety) an appeal lies to the Minister.

(c) Trees and Woodlands. The local planning authority may make a tree preservation order in relation to a single tree, to a group of trees, or to an area of woodland; such an order will not come into operation until it has been approved by the Minister.11 A landowner affected may object to the making of the order, and in that event the Minister will hold an inquiry before deciding whether to confirm the order. When a tree preservation order has so come into operation it is illegal to cut down a tree affected by the order unless consent to fell has first been obtained from the planning authority; if consent is refused, a right of appeal lies to the Minister. Failure to comply with the provisions of an order constitutes a criminal offence.

(d) Caravan Sites. Caravan sites used for human habitation are subject to a separate statutory control, contained in an Act of $1960^{12}$ and administered by local authorities. ${ }^{13}$ Before land is used as such a site, a site licence must be obtained from the local authority; conditions may be imposed on the grant of such a licence regulating matters of public health and hygiene,"4 but a licence must be granted in respect of any site for which use as such has been approved by a planning permission.

(e) Other Controls. Special forms of enforcement notice may be served requiring the tidying up of waste land, ${ }^{45}$ the cessation of a non-

${ }^{37}$ Areas declared to be of "special architectural or historic interest, the character or appearance of which it is desirable to preserve or enhance": 1971 Act, s.277. The declaration of an area to be a conservation area has but little legal effect; the only special legal provision is that any application for planning permission that may affect buildings in a conservation area must be advertised and a period of 21 days allowed in which members of the public may make observations which have to be considered by the local planning authority before making a decision on the application.

${ }^{39}$ T. \& C.P. (Amendment) Act 1972, 8.7.

${ }^{90}$ Local Authorities (Historic Buildings) Act, 1962.

${ }^{10}$ T. \& C.P. (Control of Advertisements) Regulations 1969.

1971 Act, ss.60 and 102, and the T. \& C.P. (Tree Preservation Orders) Regulations 1969.

- Caravan Sites and Control of Development Act, 1960.

is County boroughs and county district councils.

4 A right of appeal against any such conditions lies not to the Minister but to the local magistrates.

651971 Act, ss.65 and 104-107. 
conforming use that is none the less not a breach of planning control, ${ }^{46}$ and an existing planning permission may be revoked or modified. ${ }^{77}$

\section{Positive Planning}

Planning law in England and Wales has not been exclusively restrictive in its effect, although the restrictive aspects are those that most directly affect an individual landowner, and it is therefore those provisions that have been most fiercely contested in the courts. Apart from the provisions dealing with development plans, positive provisions can be summarized under four headings:

(a) Parks, national and county. The National Parks and Access to the Countryside Act, 1949, established a new public corporation, now known as the Countryside Commission (formerly the National Parks Commission) charged with the duty of defining areas of natural beauty which afford opportunities for open-air recreation, as national parks, and of advising the Minister on policy to be adopted towards such areas. These functions were widened somewhat by the Countryside Act 1968, under which the Commission was given responsibility for "the conservation and enhancement of the natural beauty and amenity of the countryside" 48

A number of National Parks have been established, but the establishment of a Park has no effect on land ownership within the Park area (except that local authorities have certain powers to acquire land to establish car parks, public lavatories, etc.) and the law of development control also is not affected, but of course the existence of a Park has a considerable influence on planning policy; it will normally be very difficult to obtain planning permission for some development on land in the Park which will adversely affect the amenities of the area. ${ }^{69}$ In spite of the name, the English National Parks are thus very different from those in the United States and Canada. In England the areas are selected for their high landscape beauty and their accessibility and it is intended that the normal farming and community life will continue.

The Act of 1968 enabled local planning authorities to provide camping sites, picnic areas and country parks in their area (whether or not within a national park). In these cases the land required is purchased by the authority (either compulsorily or by agreement) and then laid cut for the purposes indicated; a "country park" is thought of as a park or pleasure ground to be used for the purpose of providing or improving opportunities for the enjoyment of the countryside by the public. ${ }^{50}$ It is (almost) a town park in the country.

(b) New Towns. When the Minister considers it necessary to establish a new town for the purpose of taking population from over-crowded areas such as London or the West Midlands, he may, under the New Towns Act $1965^{51}$ by order designate an area of land which will normally be undeveloped, often virgin country, as being the site of a new town. The order may be subject to objections, which will be heard by an inspector appointed by the Minister, ${ }^{52}$ but once the order has become operative the next step will be for the Minister to constitute and appoint members to a "new town development corporation". This

olbid., ss.55 and 108 .

Ibid., ss.45 and 46 .

os Countryside Act 1968, s.1.

- There are now 10 National Parks in England and Wales, covering a total area of just over 5,000 square miles.

so 1 bid., ss.7 and 6 .

11 Replacing the original New Towns Act of 1946.

The inspector will hear objections to the Minister's order, and then the Minister will have to consider the inspector's report, and decide whether or not to confirm his own order: see Franklin v. Minister of Town and Country Planning [1948] A.C. 47. No orders have yet been quashed as a result of this procedure, but the Minister did modify the original order made in respect of Dawley (Staffs) as a consequence of representations made at the inquiry. 
corporate body will be put in funds by the Treasury, and will have power to acquire all or any land within the new town area compulsorily or by agreement. It will prepare a plan for the new town, in consultation with the planning authority, and will then arrange for planned residential, commercial, industrial and amenity development to be carried out in accordance with the plan either by contractors acting for the corporation, or more commonly by private developers acting under tightly-drawn 99-year leases of the land granted to them by the Corporation.

In this way the new town development corporation as owner of the land within the new town can ensure that their plan is implemented, and that a correct mix of social classes and age groups of residents will be attained, and also that the provision of homes, work and amenity facilities takes place in proper proportions. By and large the new towns of Britain ${ }^{53}$ have been successful in these objectives, although some of the first towns to be built (Crawley, in particular) had an over-large proportion of young persons among their residents. The exporting of population and industry from the overcrowded areas has proved to work more smoothly than was at one time thought possible, due partly to a special government agency known as the London Offices Bureau, whose chief concern it is to persuade large organizations to move their head offices away from Central London.

The Town Development Act, 1952, makes provision for a different, less satisfactory, procedure. Under this Act an overcrowded area, the "exporting authority", can make an agreement with a small town in the countryside having ample facilities for development, whereby the receiving authority will agree to build houses and factories for persons living in the exporting authority's area, in return for financial subsidies from the exporting authority, supplemented by further subsidies from the Central Government. This procedure is at present being employed in some half-dozen areas, but it has proved to be very complicated administratively and slow in achieving results. . $^{54}$

(c) Highways. The construction of new motorways is the concern of the Central Government, and under the Highways Act, 1959, the Minister has all the legal powers he needs to construct the roads, having acquired the necessary land, and to close existing roads which would otherwise conflict with the motorways. In exercising these powers, the Minister does not have to obtain the approval of local planning authorities but, in practice, as development plans have to be approved by the Minister, there will have been consultation at an early stage. The problems here have proved to be mainly financial, but also the administrative procedure, allowing for objections by members of the public is cumbrous and slow, although recently improved in matters of detail by the Highways Act 1971. Main roads and lesser roads are the concern of local authorities at various levels.

(d) Compulsory Acquisition. Effective positive planning must eventually depend on the government agency responsible for the planning becoming the land owner, and either carrying out the desired development themselves, or arranging for its execution by some other agency. New town development corporations and highway authorities (including the Minister) possess wide powers of compulsory acquisition ${ }^{56}$ for their own purposes, and so do local authorities under the Countryside Act 1968 for the establishment of country parks.

${ }^{53}$ Some are in Scotland; there are now nearly 30 designated areas, of which a few are fully developed.

5s There is not the same drive to get things done as there is a new town, where there is a single landlord with a single objective.

${ }_{55}$ Simplified in some minor respects by the Highways Act 1971.

${ }^{56}$ Compulsory purchase procedure follows a uniform pattern; first, there must be a statutory power authorizing acquisition for the required purpose; second that power must be applied to the particular parcel or parcels of land by the making of a compulsory purchase order, which is of no effect until it has been confirmed by the Minister (after a public inquiry into any objections); third, the compensation payable must be agreed or determined by the Lands Tribunal, and finally, the legal estate in the land must be vested in the acquiring authority. 
If, however, it is proposed to carry out an extensive scheme of redevelopment in a town centre or possibly to tackle an extensive area of slums, the planning authority will use the wide compulsory purchase power given by 8.112 of the Town and Country Planning Act 1971, or possibly in the slum clearance case, ${ }^{57}$ the older powers of the Housing Act, 1957. The 1971 Act (replacing 8.28 of the 1968 Act) provides inter alia that a local authority may be authorized by the Minister to acquire land in their area compulsorily if he is satisfied that "it is expedient to acquire the land immediately for a purpose which it is necessary to achieve in the interests of the proper planning of the area in which the land is situated". This power is so widely drafted that it would be virtually impossible for a court to declare any order made thereunder to be ultra vires. ${ }^{58}$

\section{Public Participation and "blight"}

Public participation in the planning process is a very fashionable phrase in modern English planning; ${ }^{59}$ in practice it is to be seen in the following:

(a) The representations and objections stages in the procedure for the preparation of "structure plans" and "local plans";

(b) The customary practice of the Minister in ordering publication in the locality of the impending holding of a local inquiry into an appeal against a refusal of planning permission, and the action of an inspector at such an inquiry to allow members of the public (not necessarily with any precise standing) to give evidence; ${ }^{\circ 0}$

(c) The need to advertise planning applications in conservation areas and applications for listed building consent;

(d) The requirement that applications in respect of certain noxious or unpopular forms of development ${ }^{61}$ should be locally advertised.

It is often argued that more advance publicity of the proposals of local planning authorities should be given; but if publicity is given to mere "ideas" and not proposals, there is a real danger of "blight"; because of the uncertainty, land values are (perhaps unnecessarily) depreciated.

If planning control becomes so tight that planning permission cannot be obtained for the development of a particular piece of land, and no reasonably beneficial use can be made of the land in its existing state, the land owner may by serving a "purchase notice" compel the local planning authority to acquire his interest in the land and pay him compensation on the basis of the existing use value of the land; this will not normally be a large sum but at least he will be able to unload on to the unwilling authority a "damnosa hereditas"."8

${ }^{57}$ Planning powers are often used today even in slum clearance cases, as the procedure is simpler.

${ }^{83}$ It is interesting to speculate whether similar wide powers contained in an Act of Congress or in a State statute would be held unconstitutional by the $U: S$. Supreme Court; it seems doubtful whether even Berman v. Parker 348 U.S. 26 (1954) allows the "police power" to be taken this far.

50 Partly due to a report published in 1968, under the title "People and Planning", of an inter-departmental committee under the chairmanship of the late Sir Arthur Skeffington.

${ }^{\infty}$ It has frequently been suggested that advance publicity should be given in the locality before the local planning authority consider any application for planning permission, or at least that "the neighbours" should be advised; but this is required only in a limited class of cases (see below).

- General Development Order, 1963, art. 6.

621971 Act, s.180. 
Also, if a house or commercial building ${ }^{69}$ becomes unsaleable at a reasonable price by reason of published planning proposals that will affect the property, such as a plan showing the line of a new highway, or the inclusion of the property in an action area on a structure plan, the owner will in certain circumstances be able to serve a "blight notice" on the local authority, which will have virtually the same effect as a purchase notice. ${ }^{64}$

Apart from these cases, however, undue public participation, sometimes by an uninformed or uneducated (planning-wise) public may cause quite unwarranted delay in the process, and delay usually means "planning blight" on someone's property. Planning authorities are manned by elected representatives from the area, and in a democratic country it is their responsibility to ensure that the views of the public are made known and listened to, if not always accepted.

\section{Judicial Review}

Express provision is made for an appeal to the courts on a point of law against a development plan, an enforcement notice, or certain action of the Minister, including (most significantly) a decision on an appeal to him against a refusal of planning permission. ${ }^{65}$ The last named jurisdiction has been very considerably used, and by this means an extensive jurisprudence has grown up around such questions as the meaning of development and the validity of enforcement notices, etc.

Planning law cannot, however, be declared unconstitutional in England; Parliament is supreme, and the most that the courts are able to do is to construe statutes in accordance with well established principles of the common law, where it is possible so to act within the terms of the statute. Thus, although a planning authority when granting planning permission, may under the terms of the statue impose such conditions as they think fit, any such conditions must (the power being contained in a planning statute) relate to planning matters, ${ }^{66}$ and also must not be so unreasonable as to amounting to the depriving of the landowner of his property without compensation.7

The prerogative powers of the High Court under its supervisory jurisdiction, over inferior courts and administrative bodies exercising judicial or quasi-judicial functions, ${ }^{68}$ have been rarely exercised in relation to planning authorities. ${ }^{69}$ This may be explained because those remedies are discretionary, and they will not normally be granted where statute has provided some other remedy; and there nearly always is in this context some other remedy provided. ${ }^{70}$ Further, in some cases where the supervisory remedies have been

63 Ibid., s.193.

6c Ibid., 8.194 et seq.

${ }^{63}$ Ibid., part XII.

${ }^{66}$ Mixnam's Properties Ltd. v. Chertsey U.D.C. [1965] A.C. 735.

${ }^{67}$ Express powers from Parliament would be necessary: see Hall \& Co. Ltd. v. Shoreham on Sea U.D.C. [1964] 1 All E.R. 1.

${ }^{68}$ Such for example as the prerogative orders of certiorari, mandamus and prohibition, and the action for a declaration. Injunctions are not used in English administrative law as frequently as they are in corresponding situations in the U.S.A.

69 Actions for a declaration are, however, brought on occasion (not always successfully, as in Gregory v. London Borough of Camden [1966] 2 All E.R. 196), but in most cases certiorari will not lie because there is the alternative remedy of an appeal to the Minister.

70 Nevertheless, this factor is not allowed to deprive an aggrieved person from all remedies in the courts: see Pyx Granite Ltd. v. Minister of Housing and Local Government [1959] 1 All E.R. 1. 
sought, the plaintiff has been found to have insufficient standing. ${ }^{11}$ In the compulsory purchase field, the courts have in the past scrupulously examined the terms of the statute to ensure that they justify the particular "taking" in question, but such a control becomes quite ineffective when faced with a statutory power so widely drawn as s.112 of the 1971 Act. $^{72}$

In English planning law the function of the courts can be seen as a final arbiter of difficult questions of statutory interpretation, such as the precise meaning of that key word "development", and also as a policeman to ensure that the various complicated statutory procedures are properly observed. Planning merits are not matters for the courts, nor are they concerned with the wisdom or constitutionality of the legislation.

\section{II: Planning Law in the United States}

\section{The History and Governmental Structure}

The national government of the United States is characterized principally by its federal constitutional nature. The power to govern is set out in the Constitution drafted in $\mathbf{1 7 8 7}$ at a constitutional convention called for that purpose in Philadelphia, Pennsylvania. By that Constitution, the powers to govern are divided between the national government and the regional governments of the 50 states. $^{73}$ That area of governmental activity reserved to the states is in many respects delegated by them to local government units, such as cities, villages, counties and townships, all generally referred to as municipal corporations." The term "municipality" generally refers only to cities and villages. Except in those states which have adopted state constitutional provisions $^{75}$ giving independent legal status to those municipal corporations (colloquially called "home rule" municipalities), ${ }^{76}$ municipal corporations are creatures of the state government, to be created or abolished at the will of the state legislature.

It is this fragmented governmental responsibility that is one of the principal differentiating characteristics between the British and American system of land use control. The regulation of land use is regarded as an exercise of the police power to protect the health, safety and welfare of the people. Since exercise of the police power is a function of the state governments, land use controls also remained largely a prerogative of the state,

1 Such as, for example, in Gregory v. London Borough of Camden [1966] 2 All E.R. 196, where is was held that a neighbour had no standing to raise the validity of a planning permission granted in respect of another's land.

72 See above.

7 Articles 1-3 and Amendment 10, U.S. Constitution. Hawthorn, Penniman and Zink, Government and Politics in the United States (1961) ch. 3-4. Princeton: Van Nostrand Co. The division is today largely theoretical, the notion of the states having any exclusive rights to subjects of government having long since been laid to rest by various Supreme Court decisions upholding Federal intrusion into nearly every aspect of American life.

"Since the American Revolution, states, as the repositories of legislative power, have granted charters of incorporation to cities, villages, towns, counties, and similar bodies having municipal responsibility. Hence, the term "municipal corporation".

${ }^{75}$ State governments, like the national government, also derive their powers from written constitutions which may be re-written only by the calling of a constitutional convention for that purpose (as in Illinois in 1970).

10 A home rule municipality generally must adopt a charter which serves the same purpose as a constitution for the state and Federal governments. 
rather than national, government. ${ }^{77}$ The states, in turn, have delegated most of that power to their municipal corporations-with little, if any, substantive control reserved to the state or region.

Land use controls developed very late in the history of the United States, primarily after the turn of the 20th century. As experience in other countries has demonstrated, there is little to quicken interest in such controls if there is an abundance of land. During the first century of a nation in which a strong belief in the inviolability of private property rights was coupled with a largely agrarian economy, there was no impetus at all to control the use of land. ${ }^{78}$ Land use controls in the United States finally began to develop against a backdrop of the emerging importance of the urban area, as the western frontiers of the nation steadily receded.

Thus it was in the cities, where intense use of land first developed, that it became apparent that regulations were needed to prevent one man's use of his land from depreciating the value of his neighbour's property. Rudimentary ordinances regulating building height and land use appeared in Boston and Los Angeles around 1909. In the following decade many cities passed local ordinances dividing real estate into districts which permitted some uses and excluded others. This system of local "zoning" as it came to be known, provided planners and legislators with a process containing a wide range of political options with which to achieve a consensus of interests within the local community. After the Supreme Court gave its blessing in $1926^{79}$ the issue became, what kind of restrictions and where?-rather than whether there should be restrictions at all.

The state governments also regarded land use control primarily as a device for solving problems in predominantly urban areas. An advisory committee appointed by Secretary of Commerce Herbert Hoover (as he then was) prepared a Standard Zoning Enabling Act, which was readily adopted in some form by most state legislatures. During the period following World War II the techniques of zoning became more sophisticated. The number and type of zones increased; by means of open space and floor area ratios and industrial performance standards, controls became more selective, more flexible. Finally, in the 1960s, planned unit development (PUD)-the blending of compatible uses and easing of what were by then standard restrictions in accordance with a site development plan - was added to state and municipal zoning. ${ }^{\text {on }}$

The complexity of the new techniques cannot obscure the fact that local zoning remains essentially what it was from the beginning-a process by which the residents of a local community examine what people propose to do with their land and decide whether or not they will permit it.

77 There is no Federal police power as such.

${ }^{78}$ However, as early as 1692 , a law was passed in Massachusetts Bay Colony forbidding "nuisance" industries from operating in any but certain districto designated for such uses by town officials, but the law was applied only to Boston, Salem, Charlestown, and other market towns and cities of the province -the urban areas of the day.

${ }^{79}$ Village of Euclid v. Ambler Realty Corp., 272 U.S. 365 (1926).

${ }^{80}$ Bosselman and Callies, The Quiet Revolution in Land Use Control, Washington, U.S. G.P.O., 1972; Edward M. Bassett, Zoning, New York, The Russell Sage Foundation, 1936. Cf. also, for a less reverent treatment of zoning's early history-indeed, all of zoning-Richard F. Babcock, The Zoning Game, University of Winsconsin Press, London, 1966, at pp.3-18. 


\section{State Zoning Powers}

Typically, then, the form of local land use control comes about through the local exercise of the zoning power. A state zoning enabling act, whether or not based upon the Standard Act, permits (but does not require) local governmental units to divide their territory into land use districts-usually industrial, commercial or residential, and often further subdivided within each of these three general categories-and to establish bulk (height, setback, and the like) and use regulations for each. The state enabling act may also set minimum requirements and standards for modifying or amending ordinances passed pursuant to its provisions, and require the creation of certain basic administrative agencies. Typically, both passage and amendment of the ordinance must be by the local legislative body-city council, village board of trustees, county board of commissioners or supervisors. Also typically, most enabling acts permit the modification of the terms of an ordinance in individual cases where the strict application of its terms will create a particular or unusual hardship. Such a modification, usually called a variance or exception, is customarily granted by a local administrative body called a zoning board or a board of appeals, after a public hearing. Such a hearing is also usually required before a zoning ordinance may be amended, though usually the hearing body is different from the local legislative body which actually adopts the amendment.

State zoning enabling acts are just that-enabling. Until very recently, virutally no state required the passing of local zoning ordinances, and even today only a handful actually require certain minimum land use controls to be enacted by all their local governmental units. ${ }^{82}$ The result is that, as might be anticipated from the history of zoning in the United States, in many states only the metropolitan areas are actually zoned. Huge areas of land, much of it in agricultural use, outside the boundaries of a city or village remain wholly without land use controls. Moreover, even in those rural counties where a rudimentary zoning ordinance has been enacted, the state enabling act's specific language usually exempts from the application of all zoning controls all land being used for agricultural purposes, so that much land remains unregulated even in a zoned county, while it is thus being used. This exemption from zoning regulation has even been held to remove small truck farms on the outskirts of urban areas within cities from land use controls applied under zoning enabling acts.

\section{Local Government Control of Land Use-the Zoning Ordinance}

The local zoning ordinance remains the cutting edge of land use control in the United States. Together with the subdivision control ordinance (dis-

${ }^{81}$ E.g., ch. 24, ss.11-13, et seq., Illinois Revised Statutes (1971). It is worth noting that counties on the one hand and cities and villages on the other generally are governed by separate enabling acts. Most states are so organized governmentally that the entire area is divided into county governmental units, in which cities and villages are also located. As a rule, the county zoning authority stops at incorporated city/village boundaries, which can be expanded by annexation of "unincorporated" county territory, with or without the county's blessing.

- Certain states, like Wisconsin, have recently passed legislation requiring that all counties and municipalities enact a zoning ordinance, which must be submitted to the state for approval. Failure to do so results in the state's writing such an ordinance for the recalcitrant local government unit and forcing its adoption. Unfortunately, ouch state laws rarely provide for state enforcement of such local ordinances. 
cussed infra), it is the principal means of controlling land use. Due in part to the structure imposed by the Standard Zoning Enabling Act, most zoning ordinances are similar in form, with perhaps a twist here and there to reflect local geography-or whimsy. Most local zoning ordinances, then, contain at least four distinct sections: (a) zoning map; $(b)$ district regulations; (c) nonconforming use regulations; $(d)$ administration and enforcement. There is, of course, a list of terms and definitions as well.

\section{(a) Zoning Map}

Since each ordinance relates to a specifically bounded area of land (the jurisdiction of the municipal corporation), a typical ordinance incorporates, by reference, a zoning map, which is a map of the city, village, or county with the various zoning district classifications superimposed thereon. A copy of such a map is usually required to be kept in the offices of the local government unit, to be marked with each change in district boundaries and each exception or variance granted.

\section{(b) District Regulations}

The most important part of any zoning ordinance is the dividing of the land area of the municipal corporation into land use districts and the establishment of permitted uses in each. The genesis of this theory of controlling land use has its roots in the law of nuisance and the interests of the com. munity in one's using one's land so as not to do injury to his neighbour'ssic utere tuo ut alienum non laedas. As one early commentator put it, "To permit anyone to do absolutely what he likes with his property in creating noise, smells, or danger of fire would be to make property in general valueless. To be really effective, therefore, the right of property must be supported by restrictions or positive duties on the part of the owners, enforced by the state as much as the right to exclude others which is the essence of property." Early ordinances provided for "cumulative" or "pyramidal" district zoning, in which the "highest" uses-generally low-density residential -were at the top of the pyramid and the "lowest"-heavy industrial-were at the bottom. In these early ordinances all of the higher uses were permitted in each succeeding lower use, hence the term "cumulative". As indicated earlier, the uses were generally divided into three categories: residential, commercial, and industrial.

This sort of zoning districting was early approved in a series of state decisions ${ }^{84}$ culminating in the well-known U.S. Supreme Court case of Village of Euclid v. Ambler Realty Co. ${ }^{85}$ In Euclid (which bestowed yet another name to district zoning-"Euclidean") the court basically affirmed the use of zoning by means of exclusive use districts as a valid exercise of the police power to prevent harmful effects of the right thing in the wrong place-a pig in the parlour, as it were.

In the "modern" zoning ordinance, classifications are more refined, other types of districts have been added, and many districts are no longer cumulative. It is often contrary to the terms of a zoning ordinance to build a

${ }^{83}$ Cohen, "Property and Sovereignty", 13 Cornell L.Q. 8 (1927), at p.21.

84 Such as City of Aurora v. Burns, 319 Ill. 84, 149 N.E. 784 (1925).

${ }^{85} 272$ U.S. 365 (1926). 
residence in a commercial district, for example. Although it is not unusual to have as many as 30 different classifications, a typical municipal zoning ordinance might contain this list of districts:

\begin{tabular}{cl} 
District & \multicolumn{1}{c}{ Permitted Uses } \\
R-1 & Single-family residence \\
R-2 & All R-1 and duplex \\
R-3 & Duplex and multiple-family dwellings \\
C-1 & Neighbourhood business \\
C-2 & Central commercial \\
C-3 & Highway commercial \\
I-1 & Light manufacturing \\
I-2 & Medium manufacturing \\
I-3 & Heavy industry \\
O \& R & Office and research \\
P & Public uses and universities \\
O & Parks and open space \\
A & Agriculture
\end{tabular}

Each category contains an exhaustive list of permitted uses, together with permitted accessory (garage, etc.), temporary (i.e., fruit stands, construction sheds), and special ${ }^{86}$ uses. Each district will also have a set of bulk regulations limiting, for example, the size of lot per unit, the permitted height of principal and accessory structures, minimum yard requirements, and off-street parking and loading requirements.

When drawn on a map, the districts theoretically follow a use-intensity pattern so that low-density residential uses do not abut industrial or even intensive commercial uses. In theory, the most intense use of the "higher" use district forms a buffering boundary between the least intense of the lower use districts. Thus, a row of apartment buildings in an R-3 zone might separate single-family $R-1$ districts from a business district zoned $\mathrm{C}-2$.

(c) Nonconforming Use

Since precious few municipal corporations enacted zoning ordinances before engaging in or permitting development, each zone or district was bound to have certain uses which did not conform to the new pattern. Most courts have held (or would hold) that it amounts to an unconstitutional confiscation of property to require immediately the termination of what was previously a lawful use of property merely because the said property was now placed in a district in which such use was no longer permitted. Such uses are therefore generally permitted as so-called "nonconforming uses", usually with the proviso that if they are abandoned for six months or a year, or substantially destroyed, they must be forever terminated. Nor may such uses normally be enlarged or extended or "repaired" so as to unduly extend their life. Some jurisdictions have now begun to experiment with amortization, the termination of a nonconforming use after the end of an arbitrarily determined useful life. This technique has been employed most often in eliminating low-investment nonconforming uses, such as nonconforming signs.

${ }^{86}$ A "special use" is one permitted in a district but only subject to certain articulated conditions. For example, a neighbourhood grocery may be permitted in a residential area provided it is screened, has no electric signs and is open only certain hours. The point is to preserve the character of the area, and there is no question of unique hardship-as in the case of a variation or exception. 


\section{(d) Administration and Enforcement}

The principal vehicles for administration and enforcement of a local zoning ordinance are (1) the zoning officer or administrator; (2) the zoning board of appeals; (3) the local legislative body; (4) the plan commission.

(1) The zoning administrator (who of ten serves also as the building inspector) is generally the person responsible for seeing that the provisions of the zoning ordinance are carried out. He receives complaints of violations and, if the ordinance requires them, issues zoning certificates for all uses in the village, city or county. The zoning administrator is usually appointed by the local legislative body.

(2) The board of appeals, or zoning board of adjustment, generally hears all appeals from decisions of the zoning administrator and all requests for variances or exceptions from the terms of the zoning ordinance. If the ordinances provides that such determinations are final (and many ordinances require the local legislative body to make the final decision), an appeal from its decision goes directly to the lowest level of the state judiciary (usually a circuit court) which decision is then appealable, as in any other lawsuit, through to the state Supreme Court or, if a federal question is raised (a rarity), to the federal district court. In some states, the board of appeals conducts public hearings precedent to zoning amendments or the granting of special $u_{s e}{ }^{87}$ permits as well. The typical board of appeals consists of five or seven members, appointed by the local legislative body from citizens of the local government unit.

(3) The local legislative body is responsible for enacting the zoning ordinance in its original form (usually upon recommendation of a zoning commission appointed for the purpose) and for adopting amendments thereto. The amendments, usually heard first by a recommending body such as the board of appeals or sometimes a plan commission, take two forms: textual and map. The latter, in which property is reclassified from one district to another, is by far the most common, especially in an expanding city or village which must classify or "re-zone" all territory which it annexes to its boundaries. The local governing body, if not prohibited by the state zoning enabling act, may also choose to grant not only special use permits, but also variances and exceptions to the zoning ordinance, reducing both the board of appeals and the plan commission (if any) to the role of hearing agencies only. Rarely does a local legislative body spend time actually conducting the usually required public hearings, however.

(4) The plan commission is, often as not, a non-statutory ${ }^{88}$ creation of the municipal corporation, constituted for the purpose of advising on the planning aspects of land use changes. At a minimum, the plan commission recommends on all requests for amendments and special uses. As indicated above, it usually holds public hearings as well, and may even provide planning recommendations on variance and exception requests. The commission's other principal function relates to comprehensive planning for the community, which is discussed infra in another section of this article. The plan commission is also composed of citizens appointed by the local legislative body.

Recently, yet another section has begun to appear frequently in local zoning ordinances, especially in fast-developing areas, with or without zoning enabling act sanction; the planned unit development section. Spawned by

${ }^{87}$ A "special use" is a use permitted in certain zoning districts but which does not really fit into the character of the area, and so the use is hedged around with standards and conditions to ameliorate its effects on those uses in the district which are permitted as of right.

${ }^{88}$ The planning commission, since it is often only advisory, may not be mentioned by name in a state zoning enabling act. However, some such administration agency is usually contemplated by statute to hold hearings and/or to give planning advice. 
failures of the often clumsy and arbitrary Euclidean zoning system, the planned unit development concept reflects an attempt by municipal corporations to guide development of large tracts of land in a planned, unified manner, while preserving for the developer some flexibility, without foreclosing innovative site planning and building techniques. Whether a planned unit development is permitted by means of actually re-zoning the subject property or by the granting of a special use permit which overlays existing zoning regulations, the technique is usually the same. The local legislative body is presented by the developer with a detailed land use and development plan (similar to an action-area plan in terms of detail, covering anywhere from half a dozen to hundreds of acres) for which the developer, in exchange for being permitted to develop in accordance with that plan regardless of underlying zoning restrictions, pledges himself to build only in accordance with that site plan. ${ }^{89}$ Any deviation therefrom usually requires a formal amendment to the site development plan, together with new public hearings.

This, then, in summary fashion, is an outline of the primary method of controlling land use in the United States: local zoning regulation. But it has become increasingly apparent that the local zoning ordinance, virtually the sole means of land use control in the United States for over half a century, has proved woefully inadequate to combat a host of problems of regional significance. The structure of zoning itself emphasizes very local control of land use, but in a dizzying multiplicity of local jurisdictions. While the Standard Act was a state-wide enabling act, it was nonetheless only an enabling act, directed at delegating land use control to the local level, historically at the city level where the problems which called zoning into being first arose. With few exceptions, the general manner of controlling land use in the United States remains entirely in local hands. What uniformity there is results from the initial adoption of uniform enabling legislation provided by the Standard Zoning Enabling Act-and these acts have been so heavily amended that even the common shed formerly provided is fast dwindling away.

\section{The Place of Planning in Land Use Controls}

In theory at least, land use regulation should follow comprehensive planning. Indeed, such was the original philosophy behind zoning in the United States. In 1928 the U.S. Department of Commerce promulgated a Standard City Planning Enabling Act which contemplated the establishment of a plan commission for each adopting city whose duty it was to adopt a "master plan"-a comprehensive scheme of development-for the physical development of the city. ${ }^{90}$ Even then, however, the plan was to be advisory to the governing body of the city. Herein, then, lies another crucial difference between British and American planning. Whereas the British development plan under the 1962 Town and Country Planning Act, and the Structure,

${ }^{89}$ Cf. Richard F. Babcock, Jan Krasnnowiecki and David N. McBride, "Legal Aspects of Planned Unit Residential Development", Urban Land Institute, Technical Bulletin No. 52 (Washington, D.C., 1965). It is perhaps not clear that, since a zoning district classification permits a range of uses rather than any particular one, an applicant successful in petitioning a local legislative body for a change in zoning may engage in any use permitted in that new zone classification. Generally speaking, the local authority may not condition a re-zoning on the applicant's using the subject property for a particular purpose.

${ }^{90}$ As discussed in Charles M. Haar, Land Use Planning, $A$ Casebook on the Use, Misuse and Re-Use of Urban Land, s.6, pp.344-5 (Little, Brown \& Co., Boston, 1959). 
Local and Action Area plans under the 1968 Town and Country Planning Act have the force of law upon adoption, such is rarely if ever the case with American plans, whether or not adopted pursuant to enabling legislation.

This is not to say that state enabling legislation does not contemplate master plans or comprehensive plans (though these same statutes rarely set out what such a plan is to be, what its components are). The statutes of many states permit the formulation of such a plan by a to-be-formed plan board or commission. ${ }^{91}$ Many of these same states then require the adoption thereof by local legislative bodies. ${ }^{92}$ But few require conformance to these plans after adoption. Fairly typical is a provision in the New Jersey state statutes which requires that, after the adoption of a master plan, the local governing body must refer projects to the planning board for its review and recommendation before acting upon it themselves. ${ }^{93}$ Even in those jurisdictions where the adoption of a comprehensive or master plan makes mandatory a referral to a planning board or commission which must approve or disapprove a project as being in accordance with that plan, a finding that it is not can be overridden by the local legislative body, though sometimes not without an extraordinary majority vote.94

Nor have court decisions advanced the cause of mandatory planning before zoning. While observing that good planning is important as a requisite, or even a prerequisite to effective land use controls, the judiciary have been prone to interpret planning requirements so broadly as to make them nearly meaningless. Thus Weintraub, J., summed up the matter in declaring that the term "comprehensive plan", a prerequisite to a zoning ordinance under the New Jersey enabling act, did not mean a document in some physical form outside the zoning ordinance itself: "A plan may be readily revealed in an end-product-here the zoning ordinance-and no more is required by the statute." ${ }^{\text {"9s }}$ As the Judge said (speaking probably for a goodly proportion of our judiciary): "No doubt good housekeeping would be served if a zoning ordinance followed and implemented a master plan ... but the history of the subject dictated another course."966

Under these circumstances, the comprehensive planning which is done in the United States is advisory in nature, even when reduced to a physical document. Such documents resemble nothing so much in preparation and appearance as British new town development plans. The plans themselves are generally prepared by professional consultants (unless the municipal corporation is of sufficient size to employ its own staff) for a municipal planning board or commission which sets underlying policies and guidelines for ultimate adoption by the local legislative body. A thorough plan is based upon a series of studies: population, economics, natural environment, housing, transportation, public utility, community facilities-and, of course, existing land use. The components of the physical plan, generally reduced to one volume including maps, are these: land use plans, transportation plan, and community facilities and utilities plan. In theory at least, decisions upon such as future zoning and other land use matters, capital programming and co-ordination of governmental activities will be based upon that plan.97

${ }^{91}$ Haar, op. cit. p.698 ff.

2 I.e., Maine: Public Laws 1957, ch. 405, s.2.

${ }^{98}$ Haar, op. cir., pp.7045.

94 Maine and Michigan (Haar, op. cit., p.704).

${ }^{95}$ Kozesnik v. Township of Montgomery, 131 A.2d 1 (1957).

96 Id.

${ }^{97} \mathrm{Cf}$. Norman Drummond, "The Planning Process". in Planning and Zoning in Illinois, nlinois Institute for Continuing Legal Education (1970). 


\section{Other Methods of Local Land Use Control: \\ Subdivision Ordinances and Annexation Agreements}

Two further legal devices are utilized with a good deal of success by units of local government in controlling land use-mainly development of vacant land: subdivision control ordinances and pre-annexation agreements. Both are again products of, and subject to, state enabling legislation. Both are primarily designed to control new development, often of a residential nature, on vacant land at the outskirts of settled urban areas.

\section{(a) Subdivision Control}

Most developing states have enacted statutes in the past 30 years which require the preparation and governmental approval of a scaled and precise map whenever a landowner proposes to "subdivide" a parcel of property into a number of smaller pieces. In Illinois, for example, such a map, called a plat, must be filed if a parcel is to be divided into two or more parts any one of which is less than five acres. ${ }^{93}$ The purpose of such a law is to establish and enforce standards for public facilities (streets, sewers, water mains) and parenthetically to facilitate the recording of conveyances by requiring the "platting" of subdivisions into blocks and lots, thereby eliminating the need of referring to a particular lot in a particular block of a particular subdivision by cumbersome metes and bounds description. Such laws gained much currency after the depression of the $1920 \mathrm{~s}^{.99}$

Platting itself is the method of graphically depicting lots and blocks on the subject property together with streets, alleys, utility easements and other public facilities. Most state enabling acts further permit municipal corporations to elaborate on the platting requirements by setting minimum "design standards" for the public improvements required to be installed. (Usually any improvement necessary only for his subdivision can be required of a developer to be installed at his own expense.) Generally these design standards include width of streets and sidewalks, materials which must be used in construction thereof, placement and size of water and sewer lines, placement of street lights, and the like. Recently, such ordinances have also required dedication of land for public facilities like schools and parks, though such provisions have not always been upheld in the courts. ${ }^{100}$

The procedure for subdivision plat approval is much like obtaining approval of a site plan for a planned unit development under a zoning ordinance (indeed, the procedures are so similar that some ordinances provide for combined application procedures). A "preliminary" or "final" subdivision plat is submitted to the municipal corporation in which the subject property is located. It is generally referred to a plan commission and a municipal engineer for review, then formally approved by the local legislative body, which affixes its corporate seal and signatures (mayor and clerk, usually) before a required filing wherever deeds are filed-usually with the appropriate county official, the recorder of deeds. ${ }^{101}$

Ill. Rev. Stats., ch. 109, ss.1-13 (1971).

${ }^{99}$ This was principally due to widespread delinquency in payment of special assessment bonds for assessments which had been levied to install public improvements. When the assessments could not then be paid, liens were foreclosed, but land prices were so depressed that bondholders suffered heavy losses. As a result, such bonds were difficult to sell and only by requiring the building and dedication of improvements by means of the newly-enacted subdivision control ordinance was it possible for municipal corporations to insure that such improvements would be made.

${ }_{100}$ Yokely, Zoning Law and Practice, Charlottesville (Va.): The Michie Company, 1965 , vol. II, ch. XII.

${ }^{101}$ See generally, Anderson, American Law of Zoning, vol. 4, ch. 29, Lawyers' Co-operative Publishing Company, New York, 1968. 


\section{(b) Pre-annexation Agreements}

The pre-annexation agreement is a contract between a landowner and a municipal corporation, usually state statute-authorized, whereby the latter agrees to provide proper zoning and certain municipal services (usually water and sewer) to the owner's prospective development in exchange for the owner's permitting the municipal corporation to annex the subject property, thus adding what will soon be (hopefully) valuable property to its local tax rolls.

While subdivision ordinances may be utilized by either county or city and village governments, the pre-annexation agreement obviously can be utilized only by the city or village. This is because cities and villages are generally able to expand by taking in county territory (but rarely each others); a county, on the other hand, generally has its borders fixed by state statute. It is a method by which a city or village can control the development of land along its boundaries (by expanding them), since while developers may often obtain suitable re-zoning from the county to permit the development of their land if it is not already appropriately zoned, they must generally obtain water and sewer service from a city or village which is experiencing the intense development which has made the construction of such facilities economic.

Other portions of a pre-annexation agreement usually cover the zoning to be made of the property upon annexation, the dedication of school and park lands, and cash contributions to help provide services to the newlyannexed property until such time as taxes thereon will pay for them.

\section{Ancillary Controls on the Use of Land}

It is difficult to distinguish between broad categories of "regulatory" and "positive" land use controls in the United States. As will be readily apparent from the following sections, very little actual regulating is done at the national government level-yet, by means of Federal funds, to which conditions always attach, state and local governments "accept" certain controls, generally of a planning nature. All such "positive" aspects of land use control are at the same time restrictive to the extent that Federal funding is employed. And all such controls are clearly ancillary to the basically untrammelled land use control powers of the local governments, as appears from the foregoing sections.

\section{(a) Control of Advertising Signs}

The matter of sign control in general is usually the subject of local zoning or sign control ordinances. Within limits, the size and placement of advertising signs, especially those advertising goods or services not for sale on the premises, can be regulated, even prohibited, in various. districts. On grounds of public safety, many municipal corporations prohibit altogether those signs with flashing or moving parts.

At the regional level, most states have adopted some sort of advertising sign control legislation controlling the placement of such signs along highways, principally in response to a Federal law passed in 1965 to encourage the elimination of billboards from the sides of Federal-funded highways.

The Highway Beautification Act of $1965^{102}$ is typical of land use controls at the national level in that it attempts to regulate by means of the carrot rather than the stick-or, to be more accurate in this case, by threatening to reduce the allotment of carrots. The act provides that if a state has not 
acted by January 1 of 1968 to make effective provision for effective control of the erection and maintenance along the interstate and primary highway systems of outdoor advertising within $660 \mathrm{ft}$. of the nearest edge of the rightof-way and visible from the main travel way of the system, that state's annual portion of highway construction funds ${ }^{103}$ shall be reduced by an amount equal to 10 per cent. of the amounts that would otherwise be apportioned to that state, until that state provides for effective control of such outdoor advertising signs. ${ }^{204}$ The determination of effective control is made by the Secretary of the Federal Department of Transportation. ${ }^{105}$ The act defines "effective control" as limiting outdoor advertising signs within $660 \mathrm{ft}$. of the right-of-way on interstate and primary systems to: ${ }^{106}$

(1) directional and other official signs required or authorized by law;

(2) signs advertising the sale or lease of the property on which they are located;

(3) signs advertising activities conducted on the property on which they are located.

However, the act also permits other advertising signs within the $660 \mathrm{ft}$. in areas zoned industrial or commercial "under authority of state law" (presumably local zoning ordinances passed pursuant to state enabling acts), and in unzoned commercial or industrial areas as may be determined by agreement between a state and the Secretary. ${ }^{107}$ Size, lighting and spacing of such advertising signs were originally to be determined by an agreement between the state and the Secretary "consistent with customary use". A 1968 amendment to the act, however, has made a determination of "customary use" made by a state, county or local zoning authority binding on the Secretary.

The act originally provided for five years for the removal of nonconforming signs (to July 1, 1970), and required just compensation to be paid upon the removal of outdoor advertising signs lawfully in existence on the date of the enactment of the act, those lawfully on any highway made a part of the interstate or primary system after the date of the enactment and before January 1, 1968, and those lawfully erected on or after January 1, 1968. ${ }^{103}$ The Federal government is supposed to bear 75 per cent. of that compensation, but the 1968 amendment, noted earlier on, states that no advertising sign will be required to be removed by virtue of the act if that Federal share is not available to be paid. ${ }^{109}$ Because only $\$ 2 \mathrm{~m}$. in Federal funds has been authorized since 1967 for implementing the act, precious little sign removal has taken place pursuant to the act. ${ }^{110}$ The Federal government readily admits it will take six more years to complete its programme-at a cost of $\$ 400 \mathrm{~m} .11$

${ }^{103}$ Allotted under s.104 of Title 23 of the U.S. Code.

104 Apparently this 10 per cent. penalty applies to the entire apportionment of lands to the state, not only for the interstate and primary systems, but also for the secondary system and urban extensions thereof. Cf. Rodger A. Cunningham, Control of Highway Advertising Signs, Some Legal Problems (National Cooperative Highway Research Program Report 119) Washington. National High way Research Board, National Academy of Sciences (1971).

${ }_{105}$ Chapter 23, U.S. Code (anno.), s.131 (1971 Supp.).

100 Id.

100 Id.

${ }^{108}$ Id. Such compensation was to be paid both for the taking of the sign itself and also for the taking from the owner of real property the right to erect and maintain such a sign.

100 Id.

110 Cunningham, op. cit., at p.9.

111 "Billboard Removals Will Begin In Earnest Next Year," The Wall Street Journal, December 30, 1971, at p.1. 
Although the deadline for compliance has long passed, less than one-half the states are in full compliance. Nevertheless, the Secretary has so far failed to impose the 10 per cent. penalty on a single state. ${ }^{112}$ Partly in response to this dismal record, an 11-member Commission on Highway Beautification was created in $1970^{113}$ to report to the President and Congress to recommend methods and amendments to the act which will foster its purpose.

The act clearly provides that nothing contained therein "shall prohibit a state from establishing standards imposing stricter limitations with respect to signs, displays and devices on the Federal-aid highway systems ..."114 Indeed, a few states, like Vermont, have gone so far as to wholly ban billboards from highways. ${ }^{115}$ The basic provisions of the Vermont law are:

(1) The banning of outdoor advertising from all highways.

(2) The substitution of private directional signs of access to state-owned and controlled centres, to be erected in highway rights-of-way and limited to businesses serving the travelling public.

(3) The creation of a seven-member Travel Information Council to determine what businesses are eligible for signs and where the signs are to be placed.

Within 30 days from receipt of an order by the Travel Information Council (which must certify that an area is adequately provided with official business directional signs) the owner must remove (or direct the highway department to remove without charge to him) any sign or billboard. An exception is provided for those signs which were licensed prior to the effective date of the statute, giving the owner five years for ultimate removal. Compensation is provided only for those signs which are removed pursuant to Federal statute, discussed above, and to the extent funds are provided for their removal by Congress. ${ }^{116}$

But by and large much of the regional control of outdoor advertising that has come forth from the states has been in response to the Federal act. Only 14 have passed statutes regulating highway advertising that is not intended to be responsive to the act (but only three states have no such control at all). ${ }^{117}$ Success has been spotty under such state statutes. While New Hampshire and Washington have removed over 1,000 signs and billboards each, Utah has removed only 122 , and Idaho only eight. ${ }^{118}$

\section{(b) Historic Preservation}

The preservation of landmarks and historic buildings in the United States takes place primarily at two levels: national and local. Of the two, local efforts are more successful in terms of both quantity and quality of edifices preserved.

(1) National Efforts. Our national posture with respect to historic preservation has been described recently as standing "with our feet in the

${ }^{112}$ Cunningham, op. cit., at p.8.

113 Federal-Aid Highway Act of 1970, Pub. L. no. 91-605.

116 Op. cit., note 100.

15 Act No. 333, An Act to Provide Services for Tourists and to Regulate Outdoor Advertising (April 8, 1968).

${ }^{116} \mathrm{Cf}$. Bernard D. Johnson, "Vermont Acts to Ban Billboards and Signs," $32 \mathrm{New}$ York State Planning News, pp.4, 24 and 25 (July-August 1968).

${ }^{117}$ A full discussion of the statutes of those states which have passed enactments complying with the act, together with a good many which have not, is contained in chapter 2 of the Cunningham report, cited supra, note 104.

118 "Billboard Removals Will Begin in Earnest Next Year," op. cit., p.1. 
mud, our hands tightly clutching the national purse, talking out of both sides of our mouth, echoing European concern with the values of preservation but carefully avoiding any substantial action." 119 The first national foray into historic preservation was in 1906 with the passage of the "Antiquities Act" giving the President the power to designate by proclamation such monuments as were deemed historically worthy of preservation on both Federal property and property to be acquired by the Federal government for the purpose of preservation. ${ }^{120}$ The preservation of historic sites was further declared to be a national policy in the Historic Sites Act of $1935,{ }^{121}$ but the most visible of efforts at the Federal level is the National Trust for Historic Preservation. ${ }^{122}$ Chartered by Congress in 1949 to further the declared policy of the 1935 act, the Trust is authorized to receive sites and buildings as donations. However, since Congress provided insufficient funds, the acquiring corporate arm of the Trust remains largely privately financed, with the result that in its first 14 years of operation it owned but five buildings. ${ }^{123}$ Further amendments to the act in 1966 have proved largely inadequate in terms of funding, with the donor not only having to pay at least 50 per cent. of any restoration (or obtain that amount elsewhere), but also having to supply funds for maintenance after restoration as well. ${ }^{124}$

Despite inadequate funding, the Trust continues to provide a fairly wide range of consultative services in aid of historic preservation. It sponsors seminars and conferences, disseminates model ordinances and statutes, and provides local historic preservation groups with the names of attorneys to whom they may turn to for advice. ${ }^{125}$

The U.S. Department of Housing and Urban Development (HUD), though less visible in the field of historic preservation, seems to have done more substantially to accomplish it. HUD contributed funds to make historic structures habitable and marketable (though it could not contribute to historic restoration and maintenance) ${ }^{126}$ HUD's preservation activities are considerably expanded by the Demonstration Cities and Metropolitan Development Act of $1966 .{ }^{127}$ Under this act, HUD may grant to local and state agencies up to 50 per cent. of the cost of acquiring permanent interests in areas, sites and structures of historic or architectural value in urban areas and in their restoration and improvement for public use and benefit in accordance with the comprehensively planned development of the locality. Under an earlier-noted provision, HUD may also grant to the National Trust up to $\$ 90,000$ for restoration and renovation of historic buildings-provided this does not exceed 50 per cent. of such costs and further provided that none of the amount be used for acquisition. ${ }^{228}$

119 Comment: "Legal Methods of Historic Preservation," 19 Buffalo L. Rev. 611 (Spring 1970).

120 "Background of Historic Preservation," 31 N.Y. State Planning News, no. S (Sept.-Oct. 1967), pp.1, 9.

1916 U.S. Code, s.461 (1960).

12216 U.S. Code, s.468 (1960).

129"Legal Methods of Historic Preservation," op. cit. at p.628.

12416 U.S. Code, s.470 (1970).

125 Interview with Michael DeHaven Newsom, attorney, speaker and member of the National Trust for Historic Preservation, February 18, 1972, Chicago.

12642 U.S. Code, s.1500 (1966). Under various other laws, HUD also contributed funds for the upgrading of, and providing public facilities for, areas of historical significance without actually funding preservation per se.

12742 U.S. Code, s.1500 (1966).

${ }^{128} 16$ U.S. Code, s.4706-1 (1970). 
It is worth noting that pursuant to the 1935 act the National Park Service surveyed and listed historic buildings and sites in the United States and in 1960 set up a Registry of National Historic Landmarks "for sites of exceptional value in private or semi-private hands". ${ }^{229}$ While the original list resulting from the first survey apparently contained 6,400 buildings, more recent reports indicate that close to half of these have been demolished or destroyed..$^{130}$

(2) Local Attempts to Preserve Historic Sites and Buildings. Given the nature of governmental relations between municipality and state, it is not surprising to find many local attempts at preservation grounded in state enabling acts. ${ }^{131}$ Among the most successful has been the unique preservation of the old French Quarter or "Vieux Carré" section of the City of New Orleans, in the State of Louisiana. An initial attempt was made to preserve this area by means of a city ordinance as early as 1925 , establishing a Vieux Carré Historic Preservation Area consisting of 22 full squares and parts of 24 others, and creating a commission to study and recommend action to the city council. ${ }^{132}$ The original commission was apparently largely inactive, and preservation only began in earnest with the passage of a State Constitutional Amendment in 1936 defining the Vieux Carré District, authorizing the creation by New Orleans of a Vieux Carré Commission, and giving the city council the power to pass ordinances preserving the district and exempting the buildings therein from municipal taxation. ${ }^{133}$

Under the authority of this constitutional provision, the City of New Orleans passed a number of ordinances creating the Vieux Carré Commission, defining its powers and duties, and setting up detailed sign and sign permit requirements. Essentially, the commission is granted limited control over the architecture of private and semi-private buildings erected on or abutting public streets in the district. Permits from the commission are required for painting or demolishing existing buildings, new buildings, alterations or additions. Permits are also required for exterior markings on buildings fronting on alleys and public streets. ${ }^{134}$

The constitutionality of the Vieux Carré ordinance has been attacked three times: once on the ground that the Constitutional Amendment granted only the power to regulate "front" portions of buildings of "historical or architectural worth"; 135 once on the ground that the Amendment did not authorize sign restrictions; ${ }^{136}$ and once on the ground that such sign restrictions as were authorized were too vague for enforcement. ${ }^{137}$ The Supreme Court of Louisiana upheld the ordinance against all three challenges. Only once has that court struck down an amendment to the Vieux Carré ordinance

129 "Legal Methods of Historic Preservation," op. cit. at p.628.

${ }^{130}$ Id. See also, Costonis, "The Chicago Plan: Incentive Zoning and the Preservation of Urban Landmarks," 85 Harv. Law Rev. 574 (January 1972).

131 Morrison, Historic Preservation Law, Washington: The National Trust for Historic Preservation (1965) at pp.61-186.

${ }_{132}$ "Vieux Carré Historic District Demonstration Study-Legal and Administrative Aspects of the Vieux Carre," Bureau of Governmental Research, New Orleans, Louisiana (Dec. 1968), at pp.I-1 and I-5-I-6.

133 Article XIV, s.22A of the Louisiana State Constitution.

131 Vieux Carré Ord. no. 14, 538 C.C.S., as amended (reproduced in Morrison,

Historic Preservation Law, New Orleans: Pelican Publishing Co. (1951), pp.86-97.

135 City of New Orleans v. Impastato, 3 So. 2d 559 (1941).

${ }^{136}$ City of New Orleans v. Pergament, 5 So. 2d 129 (1941).

${ }^{137}$ City of New Orleans v. Dan Levy, 64 So. 2 d 798 (1953). 
-in 1964, when the city council attempted to exempt certain property in the district from the commission's authority. ${ }^{198}$

The City of New Orleans has in addition passed ordinances requiring commission approval for change of use in the Vieux Carré District and requiring the maintenance of property in the district by the owners to prevent decay and deterioration. Under the latter, the commission may serve a notice to repair on a property owner, the ignoring of which can bring prosecution in municipal courts. 199

Another notable local effort has been that of New York City under the authority of the New York State Historic Preservation Enabling Act of 1956. ${ }^{10}$ That act granted municipalities authority to provide conditions and regulations not only for the protection of structures and places of special historical interest (or aesthetic interest or value) but also for the use and appearance of neighbouring property within the public view.

In response to this enabling act, the City of New York in 1965 passed the Historic Landmarks Act. ${ }^{141}$ A Landmarks Commission may hold a public hearing and designate either a landmark or a district for preservation by means of recording it with the City Registrar. ${ }^{142}$ Thereafter, with respect to any improvement of a designated building or district, the Commission may apply or impose regulations, limitations, determinations or conditions "which are more restrictive than those proposed ... [by] other provisions of law" with respect to the construction, reconstruction, alteration, demolition or use of such improvement, or the performance of minor work thereon ${ }^{169} \mathrm{~A}$ landmark may be no more than an improvement, but to be subject to designation, part of it must be 30 years or older with a special historical or aesthetic interest or value as part of the development, heritage or cultural characteristic of the city, state or nation. ${ }^{14}$ A historic district must contain improvements which have a special character or special historic or aesthetic interest or value, representing one or more periods or styles of architecture typical of one or more eras in the history of the city, and forming a distinctive section of the city.155

Any alteration, reconstruction, demolition or construction in a designnated district or on a designated site requires either a certificate of no exterior effect or a certificate of appropriateness. ${ }^{166}$ Since the Act is concerned only with the preservation of exterior appearances, if the Commission finds the proposed work in no way affects that appearance it must issue the former. If it finds, however, that the exterior appearance will be affected, then it must hold a hearing to determine whether to issue the latter. If the Commission rejects the plan of an applicant for such a permit and also finds that the owner can realize a reasonable return on his property-defined as a net annual return of 6 per cent. of the valuation of an improved parcel ${ }^{147}-$

${ }^{139}$ Vieux Carré Property Owners and Associates, Inc. v. City of New Orleans, 167 So. $2 \mathrm{~d} 367$ (1964).

199 "Legal and Administrative Aspects of the Vieux Carré," op. cit., pp.I-3, I-21I-24.

${ }^{140}$ N.Y. Gov. City Law, s.20 (McKinney, 1968).

11.1 Chapter 8-A, Landmarks Act.

142 Id., s.207-2.0 $\mathrm{j}$.

${ }^{143}$ Id., s. 207-3.0 b.

14 Id., s.207-1.0 k.

145 Id., s.207-1.0 h.

160 Id., ss.207.4.0 a(i); 207.5.0; 207.7.0.

${ }^{107}$ Id., $6.207 .1 .0 \mathrm{q}$. 
then the owner is simply prohibited from proceeding with that particular plan. If, however, a finding of insufficient return is made, the Commission itself must formulate a plan, ${ }^{148}$ which the owner may reject. Thereafter the Commission recommends the city acquire an "appropriate protective interest."119 If the city fails to do so within 90 days, the Commission must grant the applicant a notice to proceed, thereby permitting him to undertake his original plan. ${ }^{150}$

The New York Historic Landmarks Act was upheld in Trustees of the Sailors' Snug Harbour v. Platt. The court affirmatively answered the question of whether aesthetic or cultural benefit to the community was an adequate basis for exercising the police power. It further held that the act did not of itself provide for regulation so onerous as to result in an unconstitutional taking of property without due process of law..$^{151}$

Generally speaking, other local devices used for historic preservation are zoning ordinances (discussed supra), anti-neglect ordinances, acquisition by means of eminent domain, and, tangentially, urban renewal programmes. There is a question as to the use of the police power for historic preservation, but most courts sustain such an ordinance on economic grounds-benefits to local tourism, primarily. As to anti-neglect ordinances, New York City's Landmarks Act again provides a good example: ${ }^{152}$ "Every person in charge of an improvement on a landmark site or in an historic district shall keep in good repair (1) all of the exterior portions of such improvement and (2) all interior portions which, if not so maintained, may cause or tend to cause the exterior portion to ... deteriorate."

\section{(c) Highways}

Since the transportation of people and goods in the United States is primarily accomplished by means of roadways, their siting is a major planning tool. The location and siting of major highways was originally the responsibility of the individual state governments ${ }^{153}$ with lesser roads and urban streets the province of county, township, and city or village officials. In the exercise of the power to place roads, these governmental units are generally free to place the roadways wherever they please, at least with respect to any concern for comprehensive plans or zoning ordinances, once the necessary land has been acquired. However, with the ready availability

${ }_{168}$ Id., s.207-8.0 c. Said plan may include partial or complete tax exemptions, remission of taxes, and permission to alter, construct or reconstruct consistent with Commission standards.

${ }^{119}$ Id., $20701.0 \mathrm{~b}$ : “. . . any right or interest in or title to an improvement parcel or any part thereof, including but not limited to, fee title and scenic or other easements, the acquisition of which by the city is determined by the commission to be necessary and appropriate for the effectuation of the purposes of this chapter."

150 Id., 207-8.0 $\mathrm{g}(2)$.

151288 N.Y.S. 2 d 314 (1968).

152 Op. cit., note $121,8.207-10.0$.

${ }^{153}$ With the exception of United States Post Roads during the early history of the country; cf. Thomas A. Bailey, The American Pageant, Little, Brown and Co., Toronto (1956) at pp.72-73, for an account of such early roads. 
of Federal money for most major highway systems came a plethora of planning requirements and controls which tend to limit that state authority. ${ }^{154}$

Federal money is available for primary and secondary Federal-aid highway systems and for the Interstate Highway System. The Federal-aid primary system consists of connecting main highways selected by each state through a state highway department and subject to the approval of the Secretary of Transportation. The primary system consists of major roads, many of them four-lane, but without any limitations on access, resembling England's trunk roads. The Federal-aid secondary system is selected similar to the primary system except that "appropriate" local road officials must also take part in the selection process. These are primarily two-lane roads connecting smaller towns. The Interstate Highway System is a major limited-access highway network, similar to England's primary motorways. The system is not to exceed 41,000 miles, and is located so as to connect "as direct as practicable the principal metropolitan areas, cities and industrial centres ..."By law, these highways must be part of the primary system in each state. ${ }^{155}$ These Federal-aid systems, excluding the Interstate Highway System, represent 23 per cent. $(869,764$ miles) of the total road and street mileage in the United States-but carry 48 per cent. of the country's traffic. The Interstate Highway System, when completed in 1974, will carry an additional 20 per cent.$^{156}$

While state highway departments do all the planning and siting of the roads contained in the primary and secondary systems, these plans must be approved by the Federal Department of Transportation's Bureau of Public Roads in order for a state to be reimbursed with Federal funds upon completion of each project. At the outset, each state must establish a highway department to "discharge to the satisfaction of the Secretary [of Transportation] the duties of this Title."157 Each state highway department is required to prepare and submit to the Federal Highway Administrator for his approval detailed programmes of proposed projects "in such form and supported by such information as the Administrator shall require."158

The Federal Highway Administrator has issued regulations for the making and approving of site plans for highways. ${ }^{159}$ These regulations require the state's department of highways, when it is considering a traffic corridor in a particular area, to solicit the views of certain other state agencies and to hold, or provide an opportunity for holding, corridor location and design

${ }^{154}$ See generally. Title 23, United States Code ("Highways"), s.101 et seq. The moneys for these systems come principally from the Federal "Highway Trust Fund", which is an established fund in the United States Treasury, into which is paid the Federal tax on motor fuel, tyres, trucks and buses, certain accessories, and use tax on certain vehicles. (Title II of Federal-Aid Highway Act of 1956 [Highway Revenue Act of 1956], s.209.) The amount actually available to the states for the Federal-Aid systems is considerable: approximately 50 per cent. of the cost of constructing such roads, according to a Department of Transportation publication, "America's Lifelines". Cf. more particularly s.5 of the Federal Highway Act of 1968 (82 Stat. 815).

155 Title 23, op. cit., 8.103.

156 "America's Lifelines", published by the U.S. Department of Transportation's Bureau of Public Roads.

157 Title 23, op. cir., 8.302 .

${ }^{158} I d$. ch. 1 , s.1.8.

160 Policy and Procedure Memorandum 20-8, Public Hearings and Location Approval. 
public hearings in the proposed area. ${ }^{160}$ The actual report required with each submission for route approval and highway design must contain descriptions of alternates considered, discussions of anticipated social, economic and environmental effects thereof, location study reports, design study reports, appropriate maps and drawings, and a summary and analysis of the views received concerning the proposed undertaking. ${ }^{161}$

It is clear that as with other land use control measures, the Federal government has succeeded in imposing certain minimum planning standards and controls on what were originally state prerogatives-by means of providing funds with a host of strings attached.

\section{(d) New Communities}

The establishment of new communities similar to British new towns began as an entirely private venture in the United States. However, under recent Federal legislation providing financing, the national government is now involved in their development as well. New communities of the garden city sort ushered into Britain by Ebenezer Howard had their real beginnings in the United States wholly without benefit of governmental approval or supervision-even as their English counterparts, Letchworth and Welwyn Garden City, had begun..$^{163}$ Although they were never completed, the first governmental effort to create new communities was based on the demonstrated soundness of the concept. Three so-called "greenbelt towns"-Greenbelt, Maryland; Greenhills, Ohio; Greendale, Wisconsin-were planned by an agency of President Franklin D. Roosevelt's "New Deal" government during the economic depression of the 1930s. Planned for a full range of community facilities, they were to accommodate a population of approximately 10,000 each. Although all were begun and all had substantial populations within a few years, none became true new towns in terms of attracting industry and the preservation of open space. Congress finally sold them in 1949.163

New communities were again attempted in the United States in the late 1950 s and early '60s. A spate of planned communities, built primarily in the West and South-west, were announced by private developers who foresaw an end to the mass construction of identical homes developed on huge tracts

160 Id., ss.5, 6 and 10.

${ }^{161}$ Interview with Thomas Tidd, Assistant General Counsel, U.S. Department of Transportation, March 8, 1972.

${ }^{163}$ These were the planned communities of Ebenezer Howard's American pupil, Clarence Stein: Sunnyside, New York and Radburn, New Jersey. While meticulously planned, neither was ever brought to anything like the completed stage of Letchworth and Welwyn Garden City. Cf. Gurney Brechenfeld, Columbia and the New Cities, New York: Ives Washburn, Inc., 1971, at pp.111-115. There were sporadic attempts by various groups to establish new towns on the steadily receding American frontier throughout the history of the United States, but few really came to fruition. Railroad companies, especially, made such attempts. Once in a while, a new town of sorts was successfully created - at least physically - such as the wholly-owned company town of Pullman, outside Chicago, Mlinois, in 1881-1885. Cf. John W. Reps, The Making of Urban America, Princeton University Press, Princeton, New Jersey (1965), at p.421 et seq.

163 The three "new towns" were very like the English Mark I's-reasonably small, built on the outskirts of large cities (Baltimore, Milwaukee, Cincinatti), with plenty of governmental supervision. Cf. Brechenfeld, op. cit., at pp.115-120; Edward P. Eichler and Marshall Kaplan, The Community Builders, University of California Press, Berkeley, 1967, at pp.3-4. 
of land which prevailed in the United States as a result of the tremendous demand for housing following World War II.16s The first new community to gain national prominence was Reston, Virginia, outside of Washington, D.C. Of more recent vintage is Columbia, Maryland, between Washington and Boston, a joint venture of two private corporations, one a developer and the other an insurance company. Planned for 110,000 people in 29,000 dwelling units on 14,100 acres, Columbia currently has a population of around 15,000. Reston is older and larger, but it has only recently had to weather a financial crisis which resulted in the departure of its developer as its financial backers took control. ${ }^{165}$

It was in part the realization that large amounts of money were needed to finance such new communities, coupled with the prospect that new communities might be a partial answer to urban sprawl, that brought in the Federal government in the form of the Housing and Urban Development Act of $1968 .^{166}$ The essence of the act was its provision of loan guarantees to private developers of up to $\$ 50 \mathrm{~m}$. per project, with a maximum of $\$ 250 \mathrm{~m}$. for all outstanding guarantees. Essentially four types of new communities are presently eligible for these loan guarantees: ${ }^{167}$

(1) Economic-balanced new communities within metropolitan areas as alternatives to urban sprawl.

(2) Additions to existing smaller towns and cities which can be economically converted into growth centres to prevent decline and accommodate increased population.

(3) Major new-town-in-town developments within or adjacent to existing cities, including developments which would help renew centre-cities or have a beneficial effect on the city's tax base.

(4) Free-standing and self-sufficient new communities away from existing urban centres where there is a clear showing of economic feasibility, primarily built to accommodate population growth.

In December of 1970 Congress passed the Urban Growth and New Community Development Act, ${ }^{168}$ which made public as well as private developers eligible for Federal funds and doubled the amount of permissible outstanding loan guarantees to $\$ 500 \mathrm{~m} .{ }^{169}$ The Act further creates a Com-

${ }^{164}$ Eichler and Kaplan, op. cit., p.36 et seq.; Brechenfeld, op. cit., p.121 et seq. According to Eichler and Kaplan, fully 56 new communities were building by 1964, with projected populations from 10,000 (Huntington Beach, California) to 110,000 (Columbia, Maryland). Of these 56, 21 are located in one stateCalifornia. (Eichler and Kaplan, pp.185-186.)

${ }^{165}$ Articles on Reston and Columbia abound (to say nothing of the multitudinous public relations releases of the developers), but a good summary of matters concerning these as well as other new towns and the recent Federal entry into the new town movement is "The Big Move to New Towns", Eleanore Carruth, Fortune, September 1971, p.95 et seq. For more comprehensive treatment, $c f$. Brechenfeld, op. cit., ch. 6 (Reston) and ch. 8-11 (Columbia).

${ }_{166}$ Pub. L. 90-448, 82 Stats. 476. These provisions have been superseded by the Urban Growth and New Community Development Act of 1970. 85 Stat. 1970, et seq.

${ }^{167}$ These standards were repeated in Draft Regulations, Urban Growth and New Community Development Act of 1970, 36 Federal Register 14205-14214, July $31,1971$.

${ }^{168}$ Public Law 91-609, Title VII, 84 Stat. 1791, et seq.

${ }^{109}$ Id., s.713(e). See generally, Katharine A. Messenger, "Park Forest and Other Federally Sponsored New Communities" (PAS Memo. No. M-7), Chicago: American Society of Planning Officials (1971). 
munity Development Corporation empowered to loan to private developers up to $\$ 240 \mathrm{~m}$. for interest payments on loans to finance approved new communities. ${ }^{170}$ It also provides for a host of other limited-purpose loans and grants. The Department of Housing and Urban Development has guaranteed or is said to be well on the way to guaranteeing loans for six new communities, from free-standing to new-town-in-town..$^{171}$

Apparently a number of states are about to embark upon financing and otherwise facilitating new towns. New York created an Urban Development Corporation in 1968 and, according to one commentator, Maryland, Arizona, Tennessee and Kentucky have enacted similar laws. ${ }^{172}$

Despite this new governmental involvement, however, much activity in the new community movement continues to be generated in the private sector of the economy. ${ }^{179}$ The Federal government continues to act indirectly by means of loans and guarantees, while private development, in one form or another, continues to be the only direct method of new community creation.

(e) National Parks

The creation of national and regional parks is facilitated by the large amount of land in Federal and state governmental ownership. There are currently approximately $770 \mathrm{~m}$. acres of land in Federal ownership alone, accounting for nearly one-third of the land area of the United States' total land area. ${ }^{174}$ of this $770 \mathrm{~m}$. acres, $30 \mathrm{~m}$. acres are administered by the U.S. National Park Service, only half of which is actually within the boundaries of formally designated National Parks. ${ }^{175}$ With these huge acreages at its

$170 I d ., 65.729$ and 714 .

${ }^{171}$ The following is a breakdown of HUD commitments, from Carruth, "The Big Move to New Towns", op. cit., at p.147. HUD's New Towns

HUD

\begin{tabular}{|c|}
\hline $\begin{array}{c}\text { Guarantee } \\
\text { (millions) } \\
\$ 21 \\
\$ 24 \\
\$ 30 \\
\$ 18 \\
\$ 7.5 \\
\$ 24\end{array}$ \\
\hline
\end{tabular}

Jonathan, Minn.

St. Charles, Md.

Park Forest South, 111.

Flower Mound New Town, Tex.

Maumelle, Ark.

Cedar-Riverside (Mnnpls.)

172 Carruth, op. cit., pp.148-149.

${ }^{173}$ ld. pp.149-150.

174 "The Adjustment of Use Rights and Privileges," a study prepared by the staff of the Public Land Law Review Commission, Washington, D.C., September 1970 at pp.xv-xvi. At one time, the Federal Government owned approximately 2 billion acres of land, having received $233.4 \mathrm{~m}$. acres from seven of the 13 states at the time of the country's founding, and an additional billion acres over the next 100 years through purchase (Louisiana Territory; Alaska) and treaty. At first sold as a source of revenue, later much of this land was given away to individual settlers, railroads, and the like, as an inducement to settle the everreceding Western frontier. Those lands not administered by the National Parks Service are to a large extent administered by such Federal agencies as the Department of Agriculture's Bureau of Forestry, which supervises the vast National Forests. Use of such land by private individuals and corporations for both pleasure and profit is accomplished by means of permits issued by the administering agency, for such as cattle grazing, tree cutting, and the construction of summer residences. See generally, "The Adjustment of Use Rights and Privileges", pp.1-5, et seq.

175 "National Parks and Landmarks" (brochure published by the National Park Service of the U.S. Department of the Interior, Washington, D.C. (1970), pp.4-5. 
disposal, it is thus merely a matter of setting aside such land by means of Federal statute for the creation of parks. Additional lands may be acquired by the exercise of the power of eminent domain.

National parks are established by Acts of Congress, a separate statutory enactment being passed for each park. Yellowstone National Park, which sprawls over thousands of acres in the western state of Wyoming, was the first to be thus established (in 1872). The pertinent language states that the land comprising the park: " ". . is reserved and withdrawn from settlement, occupancy or sale under the laws of the United States, and dedicated and set out as a public park or pleasuring ground for the benefit and enjoyment of the people; and all persons who locate, or settle upon, or occupy any part of the land thus set apart as a public park, ... shall be considered trespassers and removed therefrom." As this statutory language indicates, a major difference between English and American parks is the permitted use of the land therein by private citizens. Except for uses like strictly-licensed visitors' facilities, such use is by and large forbidden in national parks of the United States.

Later statutes passed with respect to Yellowstone National Park made explicit that it is under the "sole and exclusive" jurisdiction of the United States and under the specific control of the Secretary of the Department of the Interior. ${ }^{177}$ Administration of the national parks since 1916 has been delegated to the National Park Service (a division of the Department of Interior), which is headed by a Director appointed by the Secretary of Interior. ${ }^{178}$ In 1970, Congress formalized the national character of the administration of national parks by creating the National Parks System.

There are 35 areas in the United States which, like Yellowstone, have been formally designated National Parks and which, as noted earlier, contain half the acreage $(14,459,596)$ in the National Park System as administered by the National Park Service. However, the National Park System contains an additional 243 areas of parklands administered by the Service which are roughly divided into three categories : ${ }^{179}$

(1) National Areas noted for size and scenic grandeur. This category includes the National Parks, but also encompasses some of our 85 National Monuments.

(2) Historical Areas, including National Monuments, National Battlefields, National Historic Sites and National Cemeteries.

(3) Recreational Areas, including National Seashores, National Parkways, and National Recreational Areas.

Having successfully "sold" the American public on the wonders of its national parks, the National Parks Service (like its English counterpart, the Countryside Commission) is now struggling with something of an overpopulation problem. The volume of tourists has recently become so great

17616 U.S. Code (Annotated), s.21 (Act of March 1, 1872, ch. 24, s.1, 17 Stat. 32). 17716 U.S. Code (Annotated), ss.22, 24.

${ }^{178}$ Id., s.1 and s.1(a)-1 (Pub. Law 91-383); see also, "Outdoor Recreation for America", a report to the President and to the Congress by the Outdoor Recreation Resources Review Commission, Washington, D.C., January 1962, at pp.18-21. 179 "National Parks and Landmarks," op. cit., generally.

${ }^{180}$ Interview with Gerald A. Waindell, Chief, Media Relations, National Park Service, U.S. Department of the Interior, March 9, 1972: "Yellowstone Master Plan," G.P.O. Doc. s.790-794, "Our National Parks, a Living 0 Heritage", Parks and Recreation (National Recreation and Parks Association Magazine), June 1970, at p.32 et seq. 
that the service is experimenting with measures to preserve the aesthetic and ecological characteristics of the parks. Control of perimeter areas are two such measures. It is fitting that one of the first parks for which such "preservation planning" is going forward is Yellowstone. ${ }^{180}$

State parks are established by state legislatures in a fashion similar to the National Parks at the Federal level. The first such park was established in California in 1864, and in 1885 New York established its state forest reserve in the Adirondack Mountains. Many states had no public lands, and so relied on gifts from both private donors and the Federal government. Especially in the 1930s, the Federal government bought up "marginal lands" which were leased to the states, eventually to become part of the state's park system. Today, much of the money for acquiring additional state park land comes either from the selling of government bonds (appropriately authorized by referendum of the people of the state) or from Federal grants or loans under appropriate Federal legislation. ${ }^{181}$

Local government units are usually empowered by state statute to acquire land for local park sites, by means of exercising their powers of eminent domain. One of the earliest examples was the acquisition in the 1850s of 700 acres by the City of New York, now the famous Central Park. Boston followed with Fairmont Park in the 1890s. A similar development was the creation of "forest preserves" by the county governments in metropolitan areas, such as that in Cook County, Illinois, near Chicago. ${ }^{182}$

\section{(f) Other Federal Programmes Affecting Land Use Control}

As noted supra in this article, the Federal government is involved in a number of aspects of land use control (highways, historic preservation, new communities) and is about to enter still others (the supervision of land uses which have regional impact, under a proposed National Land Use Policy Act, discussed infra). One area not yet discussed with respect to land use and the national government is housing-a subject in which the Federal government has been involved to an ever-increasing degree since 1933 . $^{183}$ Even a summary of the Federal effort to provide housing would exceed the length of this entire article. It is enough to touch briefly on certain aspects of recent housing-orientated legislation not already discussed, which have particular impact on land use controls generally. As will be apparent from what follows, the Federal programmes consist almost entirely of grants and loans, the acceptance of which carry along certain conditions and requirements, often of a planning nature.

\section{(1) The Housing and Urban Development Act of 1968}

The Housing and Urban Development Act of $1968^{184}$ represents a major revision in much of the Federal legislation related to housing. Under its provisions, a number of innovative Federal housing assistance programmes were inaugurated or strengthened, among which are the subsidizing of interest

181 "Outdoor Recreation for America," op. cit., pp.16-19; 137 et seq. Housing Act of 1961, 42 U.S. Code, 8.1455(a) (1964); Federal-Aid Highway Act of 1958, 23 U.S. Code, s.3-19 (1964); Water Conservation Fund Act of 1965, 16 U.S. Code, 8.460L-4 (1964); Preservation of Open Space Land Act, 42 U.S. Code, s.1500a (1964).

182 "Outdoor Recreation for America," op. cit., pp.14-16.

${ }^{183}$ The National Industrial Recovery Act, Public Law 73-67, 48 Stat. 195, authorized the use of Federal funds for the purpose of financing low-cost and slum-clearance housing.

184 P.L. $90-448,82$ Stat. 476,12 U.S.C. 1715 , et seq. 
payments on single-family home mortgages and on multiple-family building mortgages (in the latter case, the landlord-owner passes along the savings in the form of lower rents). ${ }^{185}$

Of greater significance are those provisions in the 1968 Act which deal with comprehensive planning. Amendments to an earlier statute contained in the act permit grants and loans for comprehensive planning for communities of all sizes in both rural and urban areas. ${ }^{186}$ These grants are for from two-thirds to three-fourths of the cost of a planning project, and are made to both state and municipal planning agencies. Eligible activities include the preparation of development plans, as well as their implementation.

Under the New Communities programme, discussed supra, a new community receiving loan guarantees must be placed and developed consistently with the comprehensive plan for the area in which it is located. ${ }^{187}$

\section{(2) Urban Development}

In the area of urban development, the 1968 Act provides for grants and loans to cities for urban renewal. However, before such funds are released, a city must either have submitted and received approval of an entire plan for a general area to be renewed, or have such plan in the making, and obtain approval for an interim plan of sorts. ${ }^{188}$ Similar planning is required before funds are released under those portions of the 1968 Act which were formerly the Demonstration Cities and Metropolitan Development Act of $1966 .{ }^{189}$ The 1966 Act provided aid for certain projects beyond housing alone, but only if the projects were in metropolitan areas in which it was demonstrated that comprehensive planning for the area was being carried out, the project was consistent with this planning, and the applicant was carrying out its other development activities in accordance with such planning. Moreover, certain of the applications had first to be submitted to a local metropolitan planning agency for comment as to the consistency of such proposals with the comprehensively planned development of the area prior to submission to the appropriate Federal agency. That these grants and loans are no small inducement to engage in such planning is clear from the 1970 fiscal year appropriations: $\$ 1.4$ billion for urban renewal and $\$ 1$ billion for model cities..$^{190}$

Grants are also available for urban beautification, urban improvements and a host of other related urban development projects. As in the programmes set out in more detail above, most of these programmes include technical and financial aid for planning. ${ }^{101}$

185 Sections 235 and 236 of the National Housing Act; ss.101(a) and 101(o), respectively of the Housing and Urban Development Act of 1968, cited supra. For a detailed analysis of these particular programmes, cf. Charles $L$. Edson, "Sections 235 and 236-The First Year", 2 Urban Lawyer, 14 (Winter, 1970).

${ }^{186}$ Such grants were first available under s.701 of the Housing Act of 1954 (P.L. 83-560); the present statutory authorization is found in the 1968 Act, at 40 U.S. Code 461, s.601.

18742 U.S. Code 3901, et seq., ss.401-416.

18842 U.S. Code 1469-1469(c), s.501. The latter "interim" method is the new portion of the 1968 Act, the former provisions were originally contained in the Housing and Urban Development Act of 1965. (P.L. 89-117, 79 Stat. 451).

189 P.L. 89-754, 80 Stat. 1255 .

18042 U.S. Code 1453, s.502, and 3311, s.1701. For a full discussion of the 1968 Act together with the history of the Federal Government's involvement in housing, see, Carl A. S. Coan, Jr. "The Housing and Urban Development Act of 1968: Landmark Legislation for the Urban Crisis", 1 Urban Lawyer 1, (Spring, 1969).

${ }^{191}$ Catalog of HUD Programs, U.S. Dept. of Housing and Urban Development, Washington, D.C. 


\section{(3) The A-95 Clearinghouse Process}

A further measure of national control over these aspects of land use which depend in part on Federal funds is provided by the A-95 Clearinghouse process. Section 401(a) of the Intergovernmental Co-operation Act of 1968 provides in part for the President to establish rules and regulations governing the formulation, evaluation and review of Federal programmes and projects having a "significant impact on area and community development ..." Largely in response to this language, the Office of Management and Budget, Executive Office of the President, disseminated circ. no. A-95 which contains regulations governing such evaluation and review. By its provisions, applicants for most Federal grants must notify the appropriate planning agency-state, regional or metropolitan, the designation of which must have Federal approval-and permit that agency to comment on the project for which funds are sought. ${ }^{192}$ The planning agency must be notified of the applicant's intent to apply "at the earliest feasible time". The notice must contain a summary description of the project, containing at least an estimated date by which a formal application to a Federal agency for funds will be made, the location and brief description of the project, and a brief statement of whether an environmental impact statement ${ }^{193}$ will be necessary.

According to circ. A-95, clearinghouse considerations include:

5. Subject matter of comments and recommendations.

Comments and recommendations made by or through clearinghouses with respect to any project are for the purpose of assuring maximum consistency of such project with state, regional and local comprehensive plans. They are also intended to assist the Federal agency (or State agency, in the case of projects for which the state under certain Federal grants has final project approval) administering such a programme in determining whether the project is in accord with applicable Federal law. Comments or recommendations, as may be appropriate, may include information about:

a. The extent to which the project is consistent with or contributes to the fulfilment of comprehensive planning for the state, region, metropolitan area, or locality.

${ }^{192}$ Interview with Lee Schoeneker, Office of Management and Budget, March 8, 1973. 193 "Section 102(2)(C) of the National Environmental Policy Act of 1969 (83 Stat. 853).

"Sec. 102. The Congress authorizes and directs that, to the fullest extent possible; (1) the policies, regulations, and public laws of the United States shall be interpreted and administered in accordance with the policies set forth in this Act, and (2) all agencies of the Federal Government shall:

"(C) include in every recommendation or report on proposals for legisla. tion and other major Federal actions significantly affecting the quality of the human environment, a detailed statement by the responsible official on:

"(i) the environmental impact of the proposed action,

"(ii) any adverse environmental effects which cannot be avoided should the proposal be implemented,

"(iii) alternatives to the proposed action,

"(iv) the relationship between local short-term use of man's environment and the maintenance and enhancement of long-term productivity, and

"(v) any irreversible or irretrievable commitments or resources which would be involved in the proposed action should it be implemented." [emphasis added.] 
$b$. The extent to which the project contributes to the achievement of state, regional, metropolitan, and local objectives as specified in s.401(a) of the Intergovernmental Co-operation Act of 1968, as follows :

(1) Appropriate land uses for housing, commercial, industrial, governmental, institutional, and other purposes;

(2) Wise development and conservation of natural resources, including land, water, minerals, wildlife, and others;

(3) Balanced transportation systems, including highway, air, water, pedestrian, mass transit, and other modes for the movement of people and goods;

(4) Adequate outdoor recreation and open space;

(5) Protection of areas of unique natural beauty, historical and scientific interest;

(6) Properly planned community facilities, including utilities for the supply of power, water, and communications, for the safe disposal of wastes, and for other purposes; and

(7) Concern for high standards of design.

The clearinghouse agency has 30 days in which to inform other governmental units which may be affected by the proposed project, and, if necessary, to consult with the applicant, and an additional 30 days to comment. Somewhat different provisions govern procedures for housing proposals. ${ }^{194}$

\section{Judicial Review}

Judicial review of land use decisions in the United States has generally been confined to the local or regional (state) level. To be sure, the lower (Federal district court) levels of the national judiciary will become involved should those Federal statutes which affect land use control be challenged. Moreover, there is the landmark zoning decision rendered by the United States Supreme Court, Village of Euclid v. Ambler Realty Co., ${ }^{195}$ discussed supra, and Berman v. Parker, ${ }^{196}$ a decision rendered by the same court some 30 years later, in which Mr. Justice Douglas upheld the District of Columbia's Redevelopment Act against a challenge that it constituted an unconstitutional taking of a man's property to improve the appearance of a city: ${ }^{197}$

It is within the power of the legislature to determine that the community should be beautiful as well as healthy, spacious as well as clean, wellbalanced as well as carefully patrolled ... If those who govern the District of Columbia decide that the nation's capital should be beautiful as well as sanitary, there is nothing in the Fifth Amendment that stands in the way.

But aside from periodic forays into land development decisions affected with civil rights overtones (usually concerning "exclusionary zoning)

${ }^{194}$ Cf. Richard Babcock and Fred Bosselman, Exclusionary Zoning: A Prognosis and Some Prescriptions, ch. 9 (published by Praeger Books in April of 1972); and Melvin B. Mogulof, "Regional Planning, Clearance and Evaluation: A Look at the A-95 Process", 36 Journal of the American Institute of Planners (No. 6, November 1971), at pp.418-422.

195 Village of Euclid v. Ambler Realty Corp., 272 U.S. 365 (1926).

196348 U.S. 26 (1954).

${ }^{197}$ Id., at 33.

${ }^{198}$ Southern Alameda Spanish Speaking Organization v. City of Union City. 424 F.2d 291 (1970); and Kennedy Park Homes Association, Inc. v. City of Lackawanna, 318 F.Supp. 669 (W.D. N.Y. 1970) involve municipal attempts to keep out racial and economic minorities contrary to the equal protection clause of the 14th Amendment to the Federal Constitution. 
nation's highest court has not heard a zoning case in nearly half a century, and the rest of the Federal judiciary is not far behind. This is due primarily to the fact that the matter of a Federal question does not often arise in that most common of land use cases, a zoning dispute, the Supreme Court having earlier decided in Euclid that zoning ordinance do not per se take property without due process of law in violation of the U.S. Constitution.

Therefore, it is the state courts, and usually the lower level ones at that, that finally decide zoning disputes. While practice differs somewhat from state to state, in part due to differences in enabling statutes, the system in Illinois is fairly typical. Illinois statutes provide for review of final administrative or local legislative zoning decisions directly to the county crcuit courts (lowest level). From there, appeals can be had to the intermediate Appellate Court, and thence to the Illinois Supreme Court (highest state court).

A zoning decision can be reviewed in court either as a final decision of the zoning board of appeals (which hears and usually finally determines variances and appeals from decisions of the municipal zoning officer) or by independent judicial review. In the former case, the plaintiff is limited by statute to the record made before the board (unless he chooses to raise constitutional issues) and the sole functions of the court are (1) to determine whether there is adequate evidence in the record to support the decision, and (2) to settle disputed questions of law.

In the case of an independent judicial review, the court will be asked to determine the validity of an ordinance (a declaratory judgment that the zoning is invalid) and usually to enjoin the municipality from interfering with the proposed land use. The declaratory judgment is the heart of plaintiff's case, and since it is usually a re-zoning or change in the zoning map (or the refusal of a municipality to make such a change) that is at issue, evidence is usually introduced tending to show the land uses in the general area of the site, property values, and the unreasonable or arbitrary nature of the existing or revised zoning classification with respect to plaintiff's property. If the burden of proof is carried by the applicant then the re-zoning will be declared void as an improper use of the police power which takes applicant's property (or some portion thereof by means of restriction) without due process of law.

It may also be alleged that some procedural defect (i.e., improper notice to neighbouring property owners) has made a re-zoning invalid. Such a claim can be raised by neighbours who may object to a re-zoning or special use which permits what they conceive to be an offensive use of nearby property.

In Illinois, as in most state jurisdictions, one must generally have exhausted all administrative remedies before seeking judicial review. The property owner must first have attempted to solve his difficulties with the local zoning authorities. Thus, one cannot usually attack a local zoning ordinance classification without first having sought an amendment thereto from the local city council or board of trustees. ${ }^{199}$

${ }^{199}$ Cf. R. Marlin Smith, "Judicial Review", in Planning and Zoning in Illinois, cited supra; Anderson, American Law of Zoning, vol. III, ch. 21 (Lawyers; Co-operative Publishing Co.; New York, 1968). 
Since zoning enabling legislation and, consequently, ordinances enacted pursuant to them, vary from state to state, disputes are usually confined within a state court system, and only as a last resort is precedent cited in the form of cases from one jurisdiction in the courts of another. Nonetheless, courts in the United States regularly decide questions concerning not only the constitutionality of portions of zoning ordinances, but also the wisdom thereof as well as that of amendments thereto.

\section{New Directions in Land Use Control}

There is a growing realization in the United States that certain aspects of land use control are of regional, even national significance, even though controls, largely through default, remain in the hands of local governmental units. For years the prestigious American Law Institute has been drafting a Model Land Development Code ${ }^{200}$ to govern the control of land use on a regional basis. Key aspects of the Code include a definition of development and development plans (which, incidentally, bear a striking resemblance to para. 12 of the Town and Country Planning Act, 1962), and state land development regulation and planning. The intent of the code is to give the state some control over the cases which involve development of state or regional impact, because of location (new major fragile environmental areas like wetlands, for example), type (airports, highway interchanges) or magnitude (such as a new town). It is not intended that the vast majority of cases (probably upwards of 90 per cent., according to one commentator) which do not affect more than the immediate local vicinity, would be appealable to a state agency. ${ }^{201}$

Similar provisions are coontained in a National Land Use Policy Act ${ }^{2 n 2}$ as proposed by the present government and now before Congress. The act would provide Federal assistance for the states to develop means for regulating those land use areas of regional- or state-wide concern. The key words are "large scale deveiopment" and "areas impacted by key facilities", such as airports and highway interchanges. The act would require that in order to exercise suitable control, one of the following alternatives must be adopted : ${ }^{203}$

(i) State establishment of criteria and standards subject to judicial review and judicial enforcement of local implementation and compliance;

(ii) Direct state land use planning and regulation;

(iii) State administrative review of local land use plans, regulations and implementation, with full powers to approve or disapprove.

Other requirements would include the necessity of including areas of critical environmental concern to the nation in designating and controlling such areas for the state.

${ }^{200}$ The project was initiated in 1963 with a grant from the Ford Foundation. A number of Tentative Drafts have been printed, and are available from The Executive Office, The American Law Institute, 4025 Chestnut Street. Philadelphia, Pennsylvania 19104. The subjects covered include: Land Development Plans, State Land Development Regulation, State Land Development Planning, and Judicial Review.

${ }^{201}$ Cf. Tentative Draft No. 3, Articles 7 and 8; Fred P. Bosselman. "State Land Development Regulation under the Proposed Model Code" (PAS Memo. No. M-8) Chicago: American Society of Planning Officials, 1971.

202 Senate Bill 992, House Bill 4332, 92nd Congress.

${ }^{203}$ Id., s.104(a). 
Meanwhile, the state governments have not stood idly by waiting for a Federal thunderbolt before seeing to their own regional land use problems. As early as 1961 , the State of Hawaii passed its Land Use Law creating a land use commission and dividing the entire state into conservation, agricultural, rural and urban land use districts. ${ }^{204}$ Hawaii thus became the first state governmental entity in the United States which subjected its entire land area to land use controls. The State of Vermont has in 1970 adopted a comprehensive Environmental Control Law, ${ }^{205}$. under which any residential subdivision involving lots of less than 10 acres, and any substantial commercial or industrial development, and any development of whatever sort above the elevation of 2,500ft., requires a permit from an environmental board. The act further requires the adoption of a series of state-wide plans in 1971 and 1973 to provide additional criteria for deciding permit applications. The State of California in 1965 created a San Francisco Bay Conservation and Development Commission with the power to approve or disapprove all proposed development in or along the Bay, in accordance with a plan prepared by the Commission and submitted to the California Legislature in 1969.206 And there are further such laws in Minnesota, Massachusetts, Maine, Wisconsin, Delaware and New York. ${ }^{207}$

Of perhaps equal significance is the growing involvement of the courts in local land use óecisions which tend to discriminate against economic or racial minorities. A number of state and local courts have viewed with jaundiced eye such zoning requirements as large minimum-lot size in residential zones, restrictions on multi-family housing, and the like, lumping such regulations in a category called "exclusionary zoning". A number of recent decisions declaring such practices illegal have done so on Federal constitutional grounds, resting on a theory of denial of equal protection of the law as guaranteed by the Fourteenth Amendment. ${ }^{208}$ Since the school desegregation case of Brown v. Board of Education, ${ }^{209}$ state and local laws which have intended to foster discrimination have been regularly declared contrary to the Fourteenth Amendment's equal protection clause. While traditional equal protection cases required of legislation only that it be rational in its distribution of benefits and burdens, with strong presumptions flowing in favour of rationality (and, therefore, legality), the new equal protection requires that all legislation which impinges on certain specially-protected interests of social and political equality bears a heavy burden of justification, regardless of its other rational purposes. ${ }^{\text {I10 }}$

${ }^{204}$ Hawaii Revised Statutes, ch. 205.

${ }^{205}$ Act 250 of the Vermont General Assembly: 10 Vermont Statutes Annotated (1970 Suppl.) es.6001-6091.

200 California Government Code, s.66600, et seq.

${ }^{207} \mathrm{~A}$ summary of the provisions and effects of this new wave of state land use control activity is contained in a recent (December, 1971) report prepared for the Executive Office of the President of the United States, Council on Environmental Quality, by Fred P. Bosselman and David L. Callies, entitled The Quiet Revolution in Land Use Controls.

${ }^{208}$ Section 1. "All persons born or naturalized in the United States, and subject to the jurisdiction thereof, are citizens of the United States and of the state wherein they reside. No state shall make or enforce any law which shall abridge the privileges or immunities of citizens of the United States; nor shall any state deprive any person of life, liberty, or property, without due process of law; nor deny to any person within its jurisdiction the equal protection of the laws."

200347 U.S. 483 (1953).

${ }^{210}$ Lawrence Gene Sager, "Tight Little Islands : Exclusionary Zoning, Equal Protection and the Indigent", 21 Stanford L. Rev. 767, 768 (April 1969). 
Thus, in Southern Alameda Spanish Speaking Organization v. City of Union City, ${ }^{211}$ a Federal court suggested that residents in a given community were entitled to decent housing: "It may well be as a matter of law that it is the responsibility of a city and its planning officials to see that the city's plan as initiated or as it develops accommodates the needs of its low-income families who usually-if not always-are members of minority groups."

There is yet another recent line of exclusionary zoning cases which tends to grant this right to housing to migrants to a community, to the detriment and destruction of local land use regulations which provide otherwise.

In re Appeal of Kit-mar Builders, decided in 1970 by the Supreme Court of the State of Pennsylvania, involved the refusal of a local council to rezone a parcel of land from a classification requiring 2-acre lots to one requiring a minimum of 1 acre. Holding the existing zoning invalid as applied to plaintiff's land, the court held, per Roberts, J.: ${ }^{218}$ "It is not for any given township to say who may or may not live within its confines, while disregarding the interests of the entire area."

In re Appeal of Girsch. ${ }^{213}$ also from the Supreme Court of the State of Pennsylvania, held invalid local zoning regulations of a town which permitted only single-family residences in its residential districts: ${ }^{214}$ "[The town] cannot have a zoning scheme that makes no reasonable provision for apartment uses. Nether Providence cannot permissibly choose to only take as many people as can live in single-family housing ... If Nether Providence is located so that it is a place where apartment living is in demand, it must provide for apartments in its plans for future growth; it cannot be allowed to close its doors to others seeking a comfortable place to live."

At least one state has enacted legislation giving relief to developers faced with exclusionary local zoning ordinances. In 1969, Massachusetts enacted a Zoning Appeals Law ${ }^{213}$ providing for an appeal by a qualified lowincome housing developer to a State Housing Appeals Committee from an adverse local authority decision on a re-zoning request. The standard is whether the decision was "reasonable and consistent with local needs", or whether conditions for approval were such as to make the proposed development "uneconomic".

The effect of these exclusionary zoning developments cannot help but erode the traditionally local control of land use decisions in the United States. This is, strangely enough, not only ardently hoped for by this country's liberal element who see such exclusionary zoning as parochial and snobbish, but by powerful and conservative commercial forces that would like to break open the residential housing market in certain localities. ${ }^{210}$

m1 424 F.2d 291 (1970).

21268 A.2d 765, at 768-69 (1970)

ม2 263 A.2d 395 (1970).

us Id. at 398-99.

ns 40 B Mass. Gen. Laws Ann. ss.20-23.

n10 Cf. Richard F. Babcock. "The Courts Enter the Land Development Marketplace", City (Jan.-Feb. 1971). 


\section{III: Comparative Conclusion}

An Englishman comparing the two accounts of English ${ }^{217}$ and American planning law respectively must perforce view them with a blinkered, if not a jaundiced, eye, especially as he is the author of the English account; nevertheless, an attempt will be made to consider the two objectively and to identify those features of the two systems that seem distinctive.

From a lawyer's point of view, the English is a single coherent system, full of detailed distinctions and elaborations, whereas the American is perhaps scarcely a system at all. In the United States planning, perforce by reason of the Constitution, has to be operated at state, not country-wide level, ${ }^{218}$ and therefore the keynote is variety and any single code is absent; indeed in extensive rural areas in many states, there is no law at all regulating land use planning. This very absence of a single system of law, however, has allowed the American lawyers and planners a richness of opportunities for experimentation denied to their colleagues on this side of the Atlantic. The extent to which these opportunities are now being exploited is to be seen in the very interesting report recently issued by the Council on Environmental Quality. ${ }^{219}$

In English law "development" is defined very widely (although not with pellucid clarity) 200 and so the potential control exercisable by planning authorities under the general supervision of the Department of the Environment (another feature not known in the United States) extends consistently over land use and any alteration to the environment (with the important exception of agriculture). In North America, on the other hand, even where there is an operative zoning or land use control, this has tended hitherto to be of a detailed kind, but yet somewhat fragmentary. Zoning control is concerned with such matters as density and "plat" control, distance of buildings from the street and space about buildings, ${ }^{221}$ and land use is controlled by specifying zones for particular uses.

When one examines the more modern approach of the planner, concerned primarily with positive planning, (i.e., measures taken to ensure that the optimum use is made of our land resources instead of merely preventing undesirable uses), one finds a rather different story. Here the great National and State Parks of the United States are true reservations of wild country in its natural condition; the National Parks of Britain, on the other hand, are merely areas of natural beauty, where (it is to be hoped) planning control is even stricter than elsewhere, and where certain amenities, such as picnic sites and lavatories, are provided for members of the public.

${ }^{211} \mathrm{Mr}$. Callies has referred to "British" planning; strictly this is not accurate, but the error is a venal one as the Scots have a very similar system of town and country planning statutes and regulations.

${ }^{218}$ The President has however recently established within his Executive Office, a Council on Environmental Quality. A report for the Council, prepared by Mr. F. Bosselman and Mr. Callies, entitled "The Quiet Revolution in Land Use Controls", shows a national appreciation of these problems and the innovative land use laws already operative in several states of the U.S.

219 The "Quiet Revolution", see note 218.

220 Ante.

221 Such matters as in England and Wales are controlled by the Building Regulations made under the Public Health Acts. 
The new towns were an English invention, inspired by such visionaries as Ebenezer Howard and Patrick Abercrombie, and they have perhaps proved to be the greatest achievement of English planners and lawyers. The keynote of their success has undoubtedly been the new town development corporation, a government agency for each town, backed by Exchequer subsidies and with adequate legal powers to acquire all the land in the new town area. The first significant new towns in the United States, Columbia and Reston, the products of private enterprise, ran into many difficulties, not the least being their relations with local authorities in their areas. Also, because of the profit motive, these towns do not provide accommodation for all income groups to the same extent as their English counterparts. Perhaps the second generation American new towns, fortified with government grants and loans, ${ }^{222}$ may, while keeping the imaginative architecture and landscaping of (e.g.) Reston, do more to solve the housing problems of the overcrowded and insanitary great cities.

Many American planning authorities (which are at local, not even state, level) seem to be influenced in their decisions under the zoning laws by considerations of their "tax base"; if they were to allow, for example, development of a specified kind in a particular area, would this give the authority a greater revenue from the local taxes that would result? This is partly, of course, because the boundaries of an American municipality are not necessarily fixed; if the open space near the limits of the municipality is developed, there may be a case for an extension of those limits. Also, an American local authority is not dependent on financial aid from the state or Federal treasury to the same extent as an English borough or urban district. Grants from higher authority are normally made in return for implementing some policy favoured by the Federal government (such as the somewhat unsatisfactory attempts to limit "billboards" (anglicé, advertisement hoardings) on main highways). Special controls over, for example, historic buildings, can also operate in America only in a similar manner, through the medium of a grant towards the cost, or possibly by threats to withhold a grant already promised.

With all their stupendous natural resources, and in spite of the frightening accounts of such abuses as the pollution of the Great Lakes, an English observer cannot but admit that the modern planners of America are fully conscious of the problems they have to face, and are gradually forging the necessary legal instruments to enable them to solve those problems. ${ }^{239}$ In England, with all the legal controls available to our planners, it is not so obvious that we are looking after our own environment any better.

\footnotetext{
292 Ante.

It is particularly interesting to see the influence of the English planning legislation on the American Law Institute's draft Modern Land Development Code (see above).
} 